\title{
PENSANDO COMO UM NEGRO: ENSAIO DE HERMENÊUTICA JURÍDICA ${ }^{1}$
}

\author{
THINKING AS A NEGRO: AN ESSAY ON LEGAL HERMENEUTICS
}

Adilson José Moreira

\begin{abstract}
Doutor em Direito pela Universidade de Harvard, 2013; Doutor em Direito pela Universidade Federal de Minas Gerais, 2007; Mestre em Direito pela Universidade de Harvard, 2005; Bacharel em Direito pela UFMG, 1999. E-mail: ajmoreirabh@gmail.com
\end{abstract}

Recebido em: 19/03/2017

Aprovado em: 03/05/2017

Doi: $10.5585 / \mathrm{rdb} . v 18 \mathrm{i} 7.635$

RESUMO: Este artigo utiliza um método pouco explorado nos estudos sobre hermenêutica no Brasil: o storytelling como meio de desvelamento do sentido das normas jurídicas. A experiência de um sujeito concreto, o autor deste texto, serve como ponto de partida para uma reflexão sobre a relevância da raça no processo interpretativo. Parte-se do pressuposto de que o lugar social do intérprete e as relações de poder que o definem determinam em grande parte a forma como ele compreende as funções do Direito. Isso significa que a análise da experiência de grupos minoritários pode ser uma referência importante para o debate sobre as possibilidades de promoção da emancipação social pelo sistema jurídico. Assim, no lugar das tradicionais reflexões teóricas sobre a igualdade, o artigo formula uma narrativa de caráter contra-hegemônico ao propor uma compreensão desse princípio a partir da voz de um sujeito subalterno.

Palavras-chave: storytelling, igualdade, hermenêutica, justiça constitucional, identidade racial.

\begin{abstract}
This article applies a method rarely explored in the studies on hermeneutics in our country: storytelling as a means of unveiling the meaning of legal norms. The personal experience of a concrete subject, the author of this essay, operates as a reference for considerations about the relevance of race in the interpretive process. It claims that the social place of the interpreter and the relations of power that defines its position in various social hierarchies determine to a large extent the way in which he understands the role and purposes of law in a democratic society. This means that the experiences of minority groups can be an important reference for the debate about the possibilities of social emancipation through legal interpretation. Thus, instead of the traditional theoretical discussions about equality, the article formulates a counter-hegemonic narrative based on an understanding of law from the perspective of a subaltern subject.
\end{abstract}

\footnotetext{
1 Este trabalho é produto da cooperação intelectual com professores e alunos da Faculdade de Direito da Universidade Presbiteriana Mackenzie. Agradeço os comentários dos membros do Grupo de Leitura dos Professores da Faculdade de Direito da Universidade Presbiteriana Mackenzie, principalmente a Arthur Roberto Capella Giannattasio, Eduardo Altomare Ariente, Humberto Barriounuevo Frabretti, José de Resende Júnior, José Francisco Siqueira Neto, Júlio César de Oliveira Vellozo e Mário André Machado Cabral. Também sou grato pelas sugestões de Joice Berth (Câmara Municipal de São Paulo), de Mara Marçal Salles (PUC-Minas) e de Rafael Polidoro Alves Barbosa (Universidade de Harvard). Também devo agradecer os membros do Grupo de Estudos de Teorias de Discriminação da Faculdade de Direito da Universidade Presbiteriana Mackenzie: Ariel Funari, Bruna Almeida, Douglas Dantas, Fábio Magalhães, Igor Fernandes Brito, Júlia Rezende, Juliana Coelho, Mariana Magalhães e Marcus Vinícius. Dedico este trabalho a Rafael Polidoro Alves Barbosa.
}

Revista de Direito Brasileira | São Paulo, SP | v. 18 | n. 7 | p. 393 - 421 |Set./Dez. 2017 
Keywords: storytelling, equality, hermeneutics, constitutional justice, racial identity SUMÁRIO: Prólogo, 1 - Pensar como um negro: considerações iniciais; 2 - Interpretando o direito como um subalterno; 3 - O jurista negro e a mitologia liberal; 4 - Pode um jurista negro interpretar as normas jurídicas de forma objetiva?; 5 - Qual é o lugar da raça na interpretação jurídica?; 6 - O humanismo racial brasileiro: nosso racismo particular; 7 - Sobre a importância do protagonismo negro; 8 - Algumas considerações sobre o privilégio; 9 - Qual é o sentido da igualdade para um jurista negro?; Conclusão; Referências Bibliográficas.

\section{PRÓLOGO}

Meu pai me contava muitas histórias quando eu era criança. Devo dizer que eu gostava de ouvir esses casos; era uma das poucas oportunidades que tinha de ter um contato mais próximo com um homem que ainda trabalhava muito, mesmo depois de sua aposentadoria. Porém, confesso que essas histórias começaram a me constranger quando atingi a adolescência. Não porque elas tivessem deixado de ser significativas para mim ou porque estivesse mais interessado nas experiências dos meninos da minha idade. Vários desses casos eram relatos de situações de discriminação, de lutas pessoais, de desestruturação familiar, de perda de vidas. Quase todas elas mostravam de uma forma ou de outra como a raça pode impedir que alguém tenha acesso às oportunidades necessárias para uma vida dignificada. Meu constrangimento assumiu a forma de tristeza ao perceber que ele teria sido um homem muito bem-sucedido se os obstáculos presentes nessas histórias não existissem. Suas narrativas demonstravam que ele era um indivíduo de grande inteligência analítica, uma pessoa muito disciplinada, um sujeito perseverante. Ele começou a trabalhar aos nove anos de idade para ajudar a sustentar a sua família. Meu pai fazia parte da turma do ferrinho, grupo de trabalhadores que andavam pelas ruas retirando o mato que crescia entre as pedras que pavimentavam as ruas e avenidas de Belo Horizonte. Ele depois trabalhou em outros setores da limpeza urbana e mais tarde chegou ao cargo de auxiliar de topógrafo. Permaneceu na escola por apenas quatro anos. Porém, ele se orgulhava imensamente do pouco tempo de educação formal. Ele sempre achou que a pouca escolarização que teve era melhor da que seus filhos e filhas tiveram acesso. Meu pai fez todo o possível para que nós usufruíssemos as oportunidades educacionais que lhes foram negadas, embora suas parcas condições financeiras dificultassem isso. Todos nós concluímos um curso superior. Apesar dessa imensa conquista, nunca deixei de sentir grande amargor por ele não ter tido as chances para que também pudesse ter explorado todas as suas imensas qualidades.

Recentemente participei de um debate sobre a legalidade de medidas de inclusão racial. Os organizadores convidaram pessoas com posições distintas sobre o tema; certos professores expressaram opiniões tidas como conservadoras e outros defenderam posturas que muitos consideram ser progressistas. Os assim chamados conservadores disseram que ações afirmativas são largamente ineficazes porque só beneficiam a classe média negra. Os progressistas, por outro lado, afirmaram que elas são necessárias por causa do preconceito racial existente no nosso país. Os que eram contra essas medidas estatais argumentaram ainda que a raça é uma categoria biológica que não deveria ser relevante para a adoção de políticas públicas. Já os membros do outro grupo disseram que ela tem consequências concretas nas vidas das pessoas, motivo pelo qual ela deve ser levada em consideração. Em um determinado momento, um desses professores progressistas pediu que eu falasse sobre a minha experiência pessoal de discriminação. Preferi fazer considerações sobre as implicações jurídicas das duas posições, mas fui interrompido porque um dos membros da mesa disse que os juristas brancos já haviam se pronunciado sobre esse tema. Eles queriam apenas a minha opinião como um homem negro. Esperavam apenas a confirmação ou a negação da existência de discriminação entre nós. Muito inconformado com o pedido, comecei a falar das minhas experiências de subordinação, mas um professor contrário a ações afirmativas alegou que meu relato não poderia ser verídico por causa da minha titulação.

Revista de Direito Brasileira | São Paulo, SP | v. 18 | n. 7 | p. 393 - 421 | Set./Dez. 2017 
Segundo ele, minha classe social impede qualquer tipo de discriminação racial, o que só atinge pobres, que são, na sua maioria, negros, razão pela qual políticas generalistas podem promover a desejada integração racial. Enquanto o professor progressista pensava que só eu poderia fazer um relato fidedigno da experiência de discriminação racial, o professor conservador argumentou que eu não represento a experiência da população negra brasileira. A figura do meu pai me veio à mente mais uma vez. Ele representaria então a situação de exclusão racial, enquanto seu filho não teria mais legitimidade para falar sobre isso? A minha titulação significa que eu consegui escapar das indignidades que negros sofrem neste país? A minha atual condição social significa que não posso mais falar pelos subordinados?

\section{PENSAR COMO UM NEGRO: CONSIDERAÇÕES INICIAIS}

Sou um jurista negro e penso como um negro. Estou afirmando que minha raça determina diretamente a minha interpretação dos significados de normas jurídicas e também minha compreensão da maneira como o direito deveria funcionar em uma sociedade marcada por desigualdades raciais. Quero então mostrar neste ensaio o que significa pensar como um jurista negro. Não estou afirmando que compreendo o sentido das palavras escritas no nosso texto constitucional de forma inteiramente diferente da maneira como juristas brancos as concebem. Estou dizendo que minha experiência social privilegia uma forma de interpretação delas, principalmente a do princípio da igualdade. Sou membro de um grupo minoritário e isso faz com que eu perceba a realidade e fale a partir de uma posição distinta de juristas que são brancos. A raça também define em grande parte a forma como eles interpretam normas constitucionais, porque ela também os situa dentro de uma posição social específica. Vejam: falo de juristas negros e juristas brancos, mas estou na verdade designando duas posturas interpretativas. Não estou identificando uma perspectiva que engloba todos os membros desses grupos. Certamente não estou defendendo nenhuma concepção essencialista da natureza humana. A figura do jurista negro com a qual me identifico compreende o Direito a partir do ponto de vista de um subalterno. Por causa disso, o Direito é interpretado como um sistema que pode ser manipulado para manter a exclusão, mas que também pode promover transformação social. A figura do jurista branco que descrevo neste artigo designa uma postura hermenêutica calcada nas premissas do individualismo, da suposta objetividade do processo interpretativo e do universalismo como parâmetros de análise dos direitos.

Este artigo examina o conflito existente entre dois tipos de discurso que pretendem ser formas legítimas de interpretação do princípio constitucional da igualdade. Argumentarei que pensar como um negro é uma perspectiva mais apta a realizar os ideais emancipatórios contidos na Constituição Federal, enquanto pensar como um branco impede o alcance dos objetivos políticos ali presentes. Muitos dirão que minha proposta é problemática porque esse documento expressa o projeto político moderno, movimento que gira em torno da construção de um aparato jurídico destinado a reproduzir os interesses de certos grupos, principalmente os dos grupos raciais dominantes. Sei que o constitucionalismo não nasceu para garantir condições dignas de existência para todos, mas não podemos esquecer que movimentos políticos liderados por grupos minoritários contribuíram de forma significativa para a expansão dos seus propósitos. É por este motivo que este artigo enfatiza essa dimensão transformadora, principalmente porque esse fato se perde quando discutimos políticas inclusivas. A defesa da neutralidade racial é um tipo de moralidade social muito difundido, motivo pelo qual seus pressupostos precisam ser examinados e, creio, refutados.

Mais uma vez, uso os termos juristas negros e juristas brancos para delinear posturas interpretativas existentes dentro da jurisprudência dos nossos tribunais sobre o princípio da igualdade. Estou falando aqui de sujeitos que habitam um campo discursivo no qual o status 
cultural e o status material influenciam a percepção e a interpretação do mundo. Esses lugares são socialmente construídos e eles precisam ser questionados para que o ideal de justiça racial que muitos de nós buscamos seja realizado (DESMOND; EMYRBAYER, 2015). Portanto, pensar como um negro significa reconhecer que a interpretação jurídica possui uma dimensão política e que ela deve estar comprometida com a reforma social. Pensar como um negro implica o reconhecimento da minha condição de membro de um grupo subalterno. É expressar descrença no doutrina liberal do individualismo, pensar a igualdade a partir de uma perspectiva transformadora, apontar os problemas com a defesa da neutralidade e da objetividade, uma característica do positivismo ingênuo e estratégico que caracteriza a interpretação da igualdade em muitas decisões judiciais sobre políticas de ações afirmativas. É também se comprometer com uma noção de justiça que possa promover tanto reconhecimento da igual dignidade de todos os membros da comunidade política quanto a redistribuição de oportunidades materiais entre eles (FRASER, 2006).

Este ensaio tem uma proposta distinta da maioria dos artigos acadêmicos. Não analisarei problemas jurídicos a partir de princípios abstratos. Quero iluminar o sentido de normas legais a partir da minha experiência pessoal como membro de uma minoria racial. Procuro com isso oferecer uma versão alternativa ao discurso dominante sobre raça na nossa sociedade, discurso que tem grande influencia sobre a maneira como nossos tribunais interpretam o princípio da igualdade. Este trabalho aplica, portanto, a metodologia do storytelling para iluminar o sentido do princípio da isonomia a partir das experiências de um membro de um grupo minoritário. Assim, essa perspectiva teórica procura oferecer uma interpretação alternativa às narrativas presentes no discurso jurídico, narrativas que não levam em consideração o lugar na raça na experiência cotidiana de subalternos. Neste ensaio, as histórias de membros de grupos minoritários servem como ponto de partida para a criação de um discurso contra-hegemônico, ponto necessário para a construção de uma sociedade mais justa. O método do storytelling está baseado na premissa de que membros de minorias possuem uma compreensão diferenciada das normas jurídicas. Essa percepção não está naturalmente associada à raça das pessoas; ela decorre do fato de que o liberalismo não permite a realização dos ideais emancipatórios propagados pelo constitucionalismo moderno. A construção abstrata dos seres humanos frequentemente utilizada de forma estratégica para manter hierarquias sociais é aqui contraposta a uma forma de raciocínio que explora as possibilidades do Direito atuar como um meio de transformação social. Uma proposta dessa natureza é relevante para o Brasil, país no qual o mito da democracia racial impede a consideração da importância da raça na vida das pessoas. Por esse motivo, considero as experiências cotidianas de indivíduos concretos, o que pode auxiliar juristas a pensar formas de interpretação inclusiva. Embora essa seja a preocupação de muitos autores liberais, a proposta de transformação social não pode estar baseada em uma visão meramente teórica do que seja a exclusão. O uso do storytelling procura resolver esse problema ao partir da experiência de pessoas que vivem a discriminação como um aspecto concreto das interações cotidianas (DELGADO; STEFANCIC, 2001, p. 37 - 48; MATSUDA, 1987, p. 325 - 340; BELL, 1992, p. 158 - 195; WILLIAMS, 1992).

\section{INTERPRETANDO O DIREITO COMO UM SUBALTERNO}

Pensar como um negro significa, primeiramente, reconhecer meu lugar como um subalterno. Esta afirmação pode parecer estranha porque sou um jurista e alguns poderiam dizer que não enfrento as mesmas dificuldades materiais que outros negros sofrem. Sempre ouço pessoas dizerem que o dinheiro embranquece, que o dinheiro protege as pessoas da discriminação. Os que dizem isso estão enganados. Minha posição no sistema de classes sociais não é o único fator que determina meu lugar social. É preciso deixar claro logo de início que questões de igualdade não podem ser discutidas a partir da premissa de que processos de 
exclusão social afetam apenas indivíduos. Sou um homem negro e isso significa que minha identidade pessoal precisa ser compreendida dentro da experiência dos membros do grupo racial ao qual pertenço. Estereótipos raciais afetam todos os membros de minorias raciais. Eles criam disparidades de status cultural e de status material entre esses cidadãos e cidadãs. Isso significa que minha vida pessoal está necessariamente relacionada com a experiência histórica das pessoas negras desta nação. ${ }^{2}$ Meus antepassados foram trazidos para este país contra a vontade deles e foram escravizados por centenas de anos. Somos vítimas de diversos tipos de discriminação, todas eles responsáveis pela preservação de uma clivagem estrutural entre negros e brancos. As transformações dos regimes políticos pelas quais passamos afetaram positivamente uma porcentagem considerável de pessoas brancas, mas elas não modificaram o status cultural e material da vasta maioria das pessoas negras no Brasil. Os projetos de dominação racial utilizados durante os períodos colonial e monárquico foram diferentes daqueles presentes na era republicana, mas todos eles procuravam manter a dominação branca. As diversas tentativas de libertação do povo negro por meio de revoluções políticas foram massacradas pelos membros do grupo racial dominante. Os meninos e as meninas negras de hoje nem sequer sabem os nomes desses indivíduos que tentaram nos afirmar como sujeitos históricos (FAUSTO, 2013; MATTOS, 2013). Em tempos mais recentes, a chance de sermos reconhecidos como pessoas que podem atuar de forma competente dentro da ordem pública foi impedida pela afirmação de um tipo de ideologia que celebrava certas tradições culturais negras como parte integrante da identidade nacional. Isso impediu a construção da raça como um meio de articulação política do meu povo e possibilitou a manutenção de privilégios raciais que pessoas brancas sempre gozaram (DOMINGUES, 2004; HASENBALG, 2005). Devo reconhecer minha condição de subalterno porque o racismo é uma força permanente dentro da sociedade brasileira, ele afeta todos os negros em todas as posições sociais, a mesma realidade presente ao longo da história deste país.

Assim, uma das principais formas de discriminação que sofremos é a dificuldade de nos afirmarmos como sujeitos políticos, de sermos reconhecidos como pessoas que têm o exercício da cidadania constitucionalmente protegido, o que situa todos nós na condição de sujeitos subordinados. Somos pessoas estruturalmente excluídas porque nossa submissão tem sido parte integrante do projeto político deste país ao longo de toda a sua história. Não recebemos o mesmo apreço cultural porque não somos valorizados da mesma forma que os membros do grupo racial dominante; não possuímos as mesmas condições de existência porque somos sempre excluídos de oportunidades materiais. Não estamos minimamente representados nas diversas instituições sociais e isso impede que nossas vozes e nossos interesses possam ser pontos relevantes para a agenda dos partidos políticos. Raramente somos ouvidos e nossas demandas não são consideradas como reinvindicações que merecem prioridade no processo decisório. Sempre enfrentamos forte oposição quando novos arranjos sociais buscam promover a nossa inclusão ou

\footnotetext{
${ }^{2}$ Ver nesse sentido BRASIL. Tribunal Regional Federal da 4 $4^{\text {a }}$ Região, Apelação em Mandado de Segurança, No. 2005.70.00.008336-7, Órgão Julgador: 3ª . Turma, Relator: Maria Lúcia Luz Vieira, DE 24/04/2008 (asseverando que a norma constitucional estabelecendo a erradicação da pobreza e da marginalidade como um dos objetivos fundamentais do nosso sistema constitucional legitima a implementação de políticas positivas destinadas a eliminar a subordinação social da população negra); BRASIL. Tribunal de Justiça do Rio Grande do Sul, Agravo de Instrumento No. 70027634401, Órgão Julgador: 3a . Câmara Cível, Relator: Paulo de Tarso Vieira Sanseverino, 05.03.2009 (“A deflagração de políticas pró-ativas, de ações afirmativas frente à questão da segregação racial, de forma a apaziguar os prejuízos impingidos a determinados grupos, excluídos de certos segmentos sociais, econômicos e culturais e com o gozo de direitos humanos e liberdades fundamentais mitigados, não revela violação ao princípio da igualdade"); BRASIL. Tribunal de Justiça do Rio de Janeiro, Representação por Inconstitucionalidade No. 9/2009, Órgão Julgador: Órgão Especial, Relator: Sérgio Cavalieri Filho ("A igualdade somente pode ser verificada entre pessoas que se encontram em situação equivalente, sendo levados em consideração os fatores ditados pela realidade econômica, social e cultural. O princípio da isonomia garante que as normas não devem ser simplesmente elaboradas e aplicadas a todos os indivíduos; vai além na medida em que considera a existência de grupos minoritários e hipossuficientes, que necessitam de uma proteção especial para que alcancem a igualdade real, esta sim uma exigência do princípio maior da dignidade da pessoa humana.")
} 
afirmar a nossa cidadania (MIGNOLO, 2006; LOOMBA, 2005). Uma nova forma de narrativa racial sempre surge para impedir que isso aconteça. Nosso sofrimento cotidiano não é tematizado e sua espeficidade é sempre negada para que as consequências do racismo branco não sejam reconhecidas. Somos, portanto, sujeitos que carecem de justiça histórica porque as consequências da discriminação racial sistemática se estendem ao longo do tempo.

Tudo isso nos situa na condição de subalternos porque temos poucas condições de transformar a realidade na qual nos encontramos. As instituições sociais geralmente operam de acordo com os interesses dos membros do grupo racial dominante e isso significa que a construção de uma agenda política transformadora encontra tremenda dificuldade. Esse é um dos motivos pelos quais um jurista negro não pode interpretar as normas constitucionais fora do seu contexto histórico, nem deixar de reconhecer que o princípio da igualdade não pode simplesmente se restringir a tratar todas as pessoas de forma simétrica, nem dizer que as medidas que procuram permitir a representatividade social de pessoas negras são inválidas ${ }^{3}$.

Assim, pensar como um jurista negro significa conceber a realidade na qual vivo a partir das condições concretas da existência, das várias restrições materiais impostas àqueles que fazem parte de grupos que estão em uma situação permanente de subordinação. Nós negros que somos operadores do Direito devemos estar conscientes de que privações fazem com que sejamos sempre socialmente classificados como membros de um grupo específico, o que elimina a possibilidade de termos nossa individualidade reconhecida. Esse estado de coisas não será alterado enquanto o status social e o status material do povo negro sejam transformados por meio de ações positivas das instituições estatais, além da mudança da forma como esses sujeitos são socialmente representados e percebidos ${ }^{4}$.

Juristas brancos pensam de forma distinta. Para eles, a discriminação racial descreve apenas uma série de ações individuais cujas consequências devem ser solucionadas por meio da responsabilização de indivíduos específicos. A solução para os problemas que negros enfrentam requer apenas a neutralização das práticas que impedem que essas pessoas, vistas como indivíduos e não como grupos, possam ter acesso a direitos ${ }^{5}$. Não preciso dizer que juristas brancos não entendem o Direito a partir da posição dos subordinados. Eles são indiferentes em

\footnotetext{
${ }^{3}$ Ver nesse sentido a petição inicial da ADPF 186 formulada pelo partido dos democratas, ação que tinha como objetivo questionar a constitucionalidade de ações afirmativas. BRASIL. Partido dos Democratas. Petição Inicial, Ação de Descumprimento de Preceito Fundamental 186, 20.07.2009 (afirmando que o princípio constitucional da igualdade exige o tratamento simétrico entre negros e brancos porque os membros desses grupos estão igualmente situados. Ver também BRASIL. Tribunal de Justiça de Minas Gerais. Mandado de Segurança no ${ }^{\circ}$ 1.0079.05.1835662/001. Relator: Albergaria Costa, 9 nov. 2006 (alegando que ações afirmativas violam o princípio da igualdade, mandamento constitucional que exige o tratamento igualitário entre todos perante a lei). BRASIL. Tribunal de Justiça do Espírito Santo. Agravo de Instrumento nº 047089000146. Órgão Julgador: Quarta Câmara Cível. Relator: Carlos Roberto Mignone. 17 fev. 2009 (Argumentando que todos os candidatos a concurso público para procurador municipal estão na mesma condição, o que mostra a desnecessidade de ações afirmativas em concursos públicos).

${ }^{4}$ Ver nesse BRASIL. Superior Tribunal de Justiça, Mandado de Segurança, No. 26.089, Órgão Julgador: 5a . Turma, Relator: Felix Fischer, DJ 12/05/2008 (afirmando que a emancipação de grupos sociais é um dos objetivos principais da noção de igualdade material uma vez que esse princípio procura estabelecer a igualdade de resultados); BRASIL. Tribunal de Justiça do Rio Grande do Sul, Agravo de Instrumento No. 70027634401, Órgão Julgador: 3a . Câmara Cível, Relator: Paulo de Tarso Vieira Sanseverino, 05.03.2009 (O princípio da isonomia deve ser analisado em perspectiva material, pois a aplicação pura e simples da igualdade formal permitiria a perpetuação de heranças discriminatórias históricas, que vêm desde a abolição da escravatura. Por isso, a necessidade de se analisar a isonomia sob a ótica de sua acepção material, buscando-se, através da promoção de oportunidades, principalmente profissionais e educacionais, expressas em políticas públicas declaradas e por intermédio da legislação ordinária, compensar os grupos menos favorecidos, no caminho da erradicação da pobreza e da marginalização, além da redução das desigualdades sociais e regionais.)

${ }^{5}$ BRASIL. Tribunal de Justiça do Espírito Santo. Agravo de Instrumento No. 02479005294, Órgão Julgador: $4^{\text {a }}$. Câmara Cível, Relator: Carlos Roberto Mignone, 170.02.2009 (alegando que apenas as pessoas que foram diretamente discriminadas devem demandar medidas reparadoras, princípio que, se desconsiderado, pode acarretar discriminação reversa);
} 
relação ao problema da subordinação racial porque pensam que o sistema jurídico deve apenas neutralizar aquelas ações irracionais que violam o ideal de tratamento simétrico. Aqui está o motivo principal pelo qual muitos deles declaram a inconstitucionalidade de ações afirmativas: a igualdade é interpretada a partir de uma perspectiva procedimental (FREEMAN, 1977, p. 1049 1060). Esse princípio serve apenas para identificar classificações irracionais e não para promover a emancipação racial ${ }^{6}$. Então, eles perguntam: qual é a relação entre raça e intelecto? Nenhuma, afinal negros e brancos possuem a mesma capacidade intelectual para serem aprovados no vestibular. Isso significa que então ações afirmativas violam o princípio da igualdade. Perceberam como esse raciocínio funciona? O foco da atitude interpretativa dos juristas brancos é a relação entre meios e fins. Membros de todos os grupos raciais possuem as mesmas condições intelectuais para alcançar seus objetivos, razão pela qual não podemos estabelecer medidas que estabelecem privilégios raciais. Como diz meu amigo Newman, falar que negros gozam de privilégios injustos é algo moralmente indecente. Entretanto, essa é a consequência da recusa de se reconhecer a realidade da estratificação racial.

Esses são alguns dos motivos pelo quais um jurista que pensa como um negro não pode compreender o Direito a partir das mesmas perspectivas que juristas brancos defendem. Um membro de um grupo subalterno não pode pensar a partir dos mesmos parâmetros impostos por aqueles que fazem parte do grupo dominante porque isso impede a afirmação de pessoas negras como sujeitos históricos. Os princípios de igualdade formal e de justiça simétrica foram importantes para a luta contra a opressão em muitas situações, mas eles não são capazes de transformar as estruturas sociais que permitem a reprodução da exclusão racial. Na verdade, eles são hoje instrumentos utilizados de forma estratégica para promover a discriminação. Sim, meus amigos. A defesa da igualdade também pode ser uma estratégia de dominação. Mas, por favor, não me julguem precipitadamente. Eu anseio por ser reconhecido como um indivíduo, mas essa forma de libertação só poderá ser alcançada quando as práticas culturais e materiais não mais operarem de forma aberta ou encoberta para reproduzir a o privilégio branco e a opressão negra.

\section{O JURISTA NEGRO E A MITOLOGIA LIBERAL}

Pensar como um negro significa expressar uma completa desconfiança do ideal individualista que anima o discurso de muitos juristas brancos. Vários deles defendem princípios liberáis. Eles partem do pressuposto de que vivemos em uma sociedade na qual as pessoas possuem as mesmas oportunidades ${ }^{7}$. Esse é um claro exemplo de como a posição que um indivíduo ocupa dentro de uma sociedade determina sua percepção dos fatos. Essa perspectiva possui uma série de problemas e o primeiro deles é a recusa de se reconhecer que o projeto liberal de construção de uma sociedade sem hierarquias nunca se concretizou. Isso não poderia

\footnotetext{
${ }^{6}$ Ver nesse sentido BRASIL. Tribunal de Justiça de Santa Catarina, Arguição de Inconstitucionalidade No. 2005.021645-7/0001.00, Órgão Julgador: Tribunal Pleno, Relator: Luiz César Medeiros, 27/09/2007 (declarando a inconstitucionalidade de um programa de ações afirmativas em curso superior porque o princípio da igualdade não admite a utilização de critério que viole o ideal da universalidade das normas jurídicas); BRASIL. Justiça Federal de Santa Catarina, Florianópolis, Ação Civil Pública No. 2008.72.00.000331-6/SC, Juiz: Gustavo Dias de Barcellos, 18. 01.2008 (afirmando que políticas raciais introduzirão o problema do racismo no Brasil, uma sociedade na qual a raça não deveria ter relevância social).

${ }^{7}$ Ver nesse sentido BRASIL. Tribunal de Justiça do Espírito Santo, Apelação Cível No. 024070612809, Órgão Julgador: 4a. Câmara Cível, Voto: Maurílio Almeida de Abreu, 15/12/2009 (declarando a inconstitucionalidade de programas de ações afirmativas baseado no argumento de que a exclusão social dos negros decorre de problemas de classe social e não de racismo); BRASIL. Tribunal de Justiça de Minas Gerais, Ação Direta de Inconstitucionalidade No. 1.0000.00.327572-4/000(1), Órgão Julgador: Corte Superior, Relator: Correa de Martins, 03/12/2003 (declarando a inconstitucionalidade de programa de cotas raciais em concurso público sob o argumento de que as desigualdades sociais entre negros e brancos decorrem da falta de investimento em políticas educacionais universais).
} 
acontecer porque o próprio Estado liberal moderno é um Estado racial. Suas instituições foram fundadas sobre a opressão negra, seus órgãos políticos permitem a continuidade da opressão negra, sua ideologia colabora com a continuidade da exclusão racial ao permitir que o mesmo grupo controle e defina os interesses nacionais ${ }^{8}$.

Sempre me lembro daqueles autores negros que falam que todas as pessoas brancas conhecem todas as pessoas negras mesmo nunca tendo encontrado todas elas, mesmo tendo pouco ou nenhum contato com elas (KANG, 2004; GREEN, 2007). Essa afirmação é relevante para a nossa discussão porque o racismo é a negação da individualidade. Um jurista que pensa como um negro não deve defender o individualismo porque está ciente de que não pode existir como um indivíduo dentro de uma ordem social baseada na estratificação racial. A frase que citei acima faz sentido porque estereótipos raciais não apenas descrevem supostas características de todos os membros de um grupo, mas também prescrevem os lugares que as pessoas devem ocupar dentro de uma sociedade (APPIAH, 2000, p. 47 - 52). Esse era um dos motivos pelos quais meus colegas brancos do primário riam de mim quando dizia que queria ser um astrônomo. "Um preto astrônomo? Isso não existe!", gritavam meus coleguinhas brancos. Essa é uma das razões pelas quais certas pessoas brancas me pedem para mostrar minha carteira profissional quando digo que sou advogado. Afinal, um negro não pode mesmo estar em lugares tradicionalmente ocupados por brancos. Temos aqui exemplos da experiência de um homem negro na sociedade brasileira: ele é uma ameaça em certas situações e um indivíduo que está fora do seu lugar natural em outras.

Sujeitos subalternos não ascendem à condição de indivíduo porque não têm condições de viver de forma autônoma. Bem, nenhum ser humano pode ser inteiramente autônomo porque a própria individualidade é constituída a partir do reconhecimento por outras individualidades. Mas, vejam, meus amigos, a situação de pessoas negras é mais problemática porque as instituições sociais são desenhadas para impedir que nós possamos alcançar uma vida digna. É por esse motivo que o discurso da meritocracia adquire a face de pura hipocrisia em uma sociedade na qual as oportunidades sociais estão inteiramente concentradas nas mãos dos membros do grupo racial dominante (TELLES, 2005, p. 139 - 172; JACCOUD, 2008, p. 65 - 97). Uma sociedade na qual metade de sua população vive na condição de subalternos nunca teve qualquer tipo de apreço pela meritocracia. Não há nela garantias de que todas as pessoas poderão alcançar seus objetivos por meio da defesa de liberdades individuais. Eu sou um homem negro e nunca ouvi algo tão imaginário quanto a ideologia da meritocracia. A vasta maioria das pessoas brancas não me percebe como um indivíduo, mas sim como um membro de uma minoria racial que possui traços bem claros, sendo que muitas deles são o oposto das supostas características de pessoas brancas, o grupo socialmente construído como ideal moral.

Um dos elementos centrais da mitologia liberal é o princípio da igualdade formal. Ele está centrado no pressuposto de que todas as pessoas devem ser tratadas da mesma forma perante as normas jurídicas. Ele também está baseado na premissa de que a justiça liberal é uma justiça simétrica, ou seja, alcançamos a igualdade quando tratamos todos as pessoas de uma mesma classe da mesma forma. Características pessoais devem então ser desconsideradas para que todas as pessoas sejam tratadas a partir da condição delas como sujeitos jurídicos. ${ }^{9}$ Esses ideais são

\footnotetext{
${ }^{8}$ Ver nesse sentido, BRASIL. Tribunal Regional Federal da $4^{\mathrm{a}}$, AI No. 2005.04.01.006358-2/RS, Órgão Julgador: $3^{\mathrm{a}}$. Turma, Relator: Luiz Carlos de Castro Lugon, DJU 01.06.2005 (dizendo que as disparidades sociais entre negros e brancos não derivam apenas de disparidades de classe, mas sim de discriminação racial sistemática, o que requer a implementação de políticas públicas promotoras da igualdade material entre esses grupos).

${ }^{9}$ Ver, por exemplo, TJMG, Apelação Cível em Mandado de Segurança No. 1.0079.05.183566-2/001(2), Órgão Julgador: $3^{a}$. Câmara Cível, Relator: Albergaria Costa, 14/09/2007 (argumentando que os programas de ações afirmativas ferem o princípio da meritocracia porque impede negros de competirem em pé de igualdade com outros grupos raciais, além de preterir as outras raças); TRF-2a ${ }^{2}$ Região, Apelação Cível No. 1999.50.01.009568-0, Órgão Relator: $8^{a}$. Turma, Relator: Guilherme Calmon, 16/03/2005 (afirmando que a implementação de programas de ações afirmativas viola o princípio da meritocracia e também o princípio da igualdade).
} 
realmente muito sedutores. Entretanto, não acredito que o liberalismo possa criar uma sociedade igualitária porque características individuais têm um papel central na vida das pessoas. Elas precisam ser consideradas para que a justiça seja alcançada. Não se pode atingir esse objetivo sem um abandono parcial do princípio da universalidade das normas jurídicas. Ao negligenciar o sentido substantivo de igualdade em nome de sua dimensão formal, juristas brancos impedem que mudanças ocorram. Esse é um dos motivos pelos quais um jurista que pensa como um negro deve interpretar o princípio da isonomia a partir da experiência daqueles que sofrem diversas formas de opressão. A promessa liberal de emancipação nunca pôde se realizar porque muitos juristas brancos interpretam normas jurídicas sem levar em consideração a experiência concreta da vida das pessoas. ${ }^{10}$ É curioso que essa perspectiva se mantenha presente mesmo depois de todas as críticas dos autores que enfatizam as conexões entre o direito e a política, mas podemos explicar isso pelo interesse estratégico dos que interpretam o Direito dessa forma (MINDA, 1997, p. 13 $62)$.

Já disse que minha existência e minhas oportunidades estão ligadas ao destino do meu grupo e isso significa que interpretar o princípio da igualdade a partir da premissa de que todas as pessoas são tratadas como indivíduos permite a perpetuação das desigualdades. Por que isso não é claro para os juristas brancos? Muitos acreditam que todas as pessoas têm a mesma experiência social que eles. Muitos pensam que negros e brancos estão na mesma condição. Outros utilizam essa perspectiva como mera estratégia de dominação. A posição interpretativa de juristas brancos é altamente problemática porque a questão racial não é analisada dentro da estrutura de dominação existente no nosso país. O sistema de desvantagens que afeta negros e o sistema de vantagens que beneficia brancos não aparecem dentro dessas considerações. Ao contrário, eles continuam reproduzindo a mitologia da democracia racial, ideologia que funciona como uma falsa consciência. Essa reprodução impede que o privilégio branco seja reconhecido e questionado. Eles defendem apenas políticas destinadas à generalidade dos indivíduos, única alternativa compatível com o pressuposto da universalidade do princípio da igualdade ${ }^{11}$. Mais problemático, a questão da raça aparece como uma forma de opressão de pessoas brancas e não como uma categoria que organiza os sistemas hierárquicos aqui existentes ${ }^{12}$.

\footnotetext{
${ }^{10}$ Ver nesse sentido BRASIL. Tribunal de Justiça do Espírito Santo. Agravo de Instrumento No 04789000146, Órgão Julgador: 4ª . Câmara Cível, Relator: Carlos Roberto Mignone, 170.02.2009 (argumentando que a adoção de ações afirmativas deve observar a utilização de critérios justificáveis para que possam estar em acordo com a igualdade, o que não inclui a raça das pessoas em concursos para cargos públicos); BRASIL. Partido dos Democratas. Petição Inicial, Ação de Descumprimento de Preceito Fundamental 186, 20.07.2009 (argumentando que o princípio constitucional da igualdade requer a aplicação de normas a negros e brancos de forma simétrica porque esses grupos estão em situação de igualdade social).

${ }^{11}$ Ver nesse sentido BRASIL. Tribunal Regional da $5^{\text {a }}$. Região. Agravo de Instrumento 61893, Órgão Julgador: $3^{\text {a }}$. Turma, Relator: Paulo Gadelha, 24.08.2006 ("A utilização da cor da raça, como critério diferenciador para o acesso a vagas nas universidades, constitui critério de segregação racial e, talvez, o mais indicado para reduzir estas diferenças seja o investimento na qualidade do ensino público, pois, este critério ajudaria não só os estudantes negros, mas, sim, todos os estudantes carentes do Brasil, independente, de raça, sexo ou religião."); BRASIL. Tribunal de Justiça do Rio de Janeiro. Ação Direta de Inconstitucionalidade No. 0009/2009, Órgão Julgador: Órgão Especial, Relator: José Carlos S. Murta Ribeiro, 25.05 .2009 ("Se há de se implementar as chamadas ações afirmativas, políticas inclusivas entre os mais desfavorecidos, que se faça esta prática de forma genérica e abrangente e não criando situações de privilégios para alguns em detrimento dos outros".)

${ }^{12}$ BRASIL. Tribunal de Justiça do Espírito Santo. Agravo de Instrumento No 04789000146, Órgão Julgador: $4^{\mathrm{a}}$. Câmara Cível, Relator: Carlos Roberto Mignone, 170.02.2009 (asseverando que a implementação de ações afirmativas poderá transformar o Brasil em uma sociedade preconceituosa em função de políticas que podem ser classificadas como discriminação reversa); TJMG, Incidente de Constitucionalidade No. 1.0000.07.449458-4/000(1), Órgão Julgador: Corte Superior, Relator: Reynaldo Ximenes Carneiro, 27/06/2007 (classificando a adoção de cotas raciais em concurso público como uma iniciativa discriminatória contra brancos porque estabelece tratamento diferenciado com base na pele dos indivíduos, o que ofende o princípio da igualdade formal entre os indivíduos); BRASIL. Partido dos Democratas. Petição Inicial, Ação de Descumprimento de Preceito Fundamental 186, 20.07.2009 (afirmando que a implementação de ações afirmativas poderá transformar o Brasil em um país preconceituoso e intolerante porque elas criam vantagens indevidas para pessoas negras).
}

Revista de Direito Brasileira | São Paulo, SP | v. 18 | n. 7 | p. 393 - 421 |Set./Dez. 2017 


\section{PODE UM JURISTA NEGRO INTERPRETAR AS NORMAS JURÍDICAS DE FORMA OBJETIVA?}

Minha experiência como um jurista negro que pensa a partir da condição de um subalterno impede que eu acredite na premissa segundo a qual o processo de interpretação é guiado pelos princípios da neutralidade e da objetividade. É curioso ter que defender essa posição no atual estágio de evolução do pensamento jurídico. Entretanto, o positivismo ingênuo continua sendo utilizado de forma estratégica no processo hermenêutico. Nunca pude sentir a experiência de um sujeito abstrato que transcende suas condições sociais. É claro que juristas brancos também não podem, porém eles levam uma vantagem: eles não são sujeitos socialmente marcados e por isso podem pensar como pessoas genéricas. Eu só tenho esse privilégio quando falo enquanto homem, discuto questões que afetam distintamente homens e mulheres e parto do pressuposto de que elas têm a mesma vivência social que a minha. Trabalho com análise de discurso e tenho lido milhares de decisões judiciais sobre questões relacionadas a direitos de minorias. Raramente vejo o sujeito cartesiano servindo como parâmetro para a interpretação das normas jurídicas que regulam esses casos, embora esses atores sociais afirmem que estejam interpretando a legislação de forma imparcial ${ }^{13}$.

Muitos juristas brancos continuam argumentando que o processo interpretativo implica a identificação da vontade objetiva contida na norma jurídica. O jurista pode descobrir o sentido objetivo da lei desde que siga os pressupostos epistemológicos que informam o discurso científico. O sentido da norma é desvelado dentro de suas possibilidades gramaticais naturalmente demarcadas pelos limites da língua. Assim, o campo das relações sociais não pode ser uma referência adequada para a interpretação. ${ }^{14}$ Um jurista negro não pode deixar se seduzir por essa perspectiva formalista porque sabe que juízes também são agentes ideológicos. Operadores do direito interpretam normas a partir dos conteúdos cognitivos internalizados no processo de socialização, além dos interesses dos grupos sociais que eles representam. Ao contrário do que dizem os defensores atuais do formalismo, juristas não são pessoas que interpretam normas a partir de critérios racionais. Muitas vezes, eles atuam com o intuito de reproduzir as relações de poder que estruturam a sociedade na qual vivem (CRENSHAW, 1987; FREEMAN, 1977; KENNEDY, 1999).

Os professores conservadores que participaram do debate sobre cotas raciais fizeram questão de enfatizar o comprometimento constitucional com a igualdade formal. Eu me lembro que um deles abriu a Constituição e leu o caput do artigo quinto para o público em tom exaltado. Bem, nenhuma outra coisa neste mundo agrada mais juristas brancos do que uma boa dose de legalismo. É claro que esse formalismo interpretativo prescinde de quaisquer considerações do contexto social no qual o tema em debate está inserido. Para eles, o sistema jurídico possui uma lógica interna. Portanto, a interpretação das leis não requer qualquer tipo de diálogo com outras áreas do conhecimento. Isso permite a eles dizer que o ato de interpretação está distanciado de quaisquer análises de valor, o que seria incompatível com o ideal de objetividade do processo hermenêutico. Mas um jurista que pensa como um negro deve, além de rejeitar esse formalismo primitivo, reconhecer que os fenômenos sociais possuem sentidos para os agentes que estão sempre interpretando as situações nas quais eles estão imersos. Repito: ser socialmente marcado como um membro de um grupo minoritário significa em grande parte abordar o mundo a partir

\footnotetext{
${ }^{13}$ Podemos classificar o questionamento judicial da constitucionalidade de ações afirmativas da Universidade de Brasília pelo Partido dos Democratas como uma clara tentativa de um grupo social de utilizar a retórica liberal para defender interesses de grupos ideológicos específicos. Ver BRASIL. Partido dos Democratas. Petição Inicial, Ação de Descumprimento de Preceito Fundamental 186, 20.07.2009.

${ }^{14}$ BRASIL. Tribunal de Justiça do Rio de Janeiro. Apelação Cível No. 06.281/04, Órgão Julgador: 9ª Câmara Cível, Relator: Marcus Tulius Alves, 14.09.2004 ("A questão é nova e mesmo que conturbada por sua colocação de alcance social está por absorver antes de tudo juízo de isenção político do magistrado obrigando-o a verter olhar em primeiro lugar sobre a verdade constitucional que impõe a igualdade de tratamento entre todos os cidadãos.").
}

Revista de Direito Brasileira | São Paulo, SP | v. 18 | n. 7 | p. 393 - 421 | Set./Dez. 2017 
do lugar social de um subordinado. Para um jurista que pensa como um negro, o formalismo jurídico não é uma perspectiva adequada de interpretação do mundo. Pelo contrário, é uma forma de percepção dos arranjos sociais que promove a exclusão.

As posições defendidas por juristas brancos conservadores e progressistas não contribuem da forma mais adequada para a construção de uma hermenêutica jurídica capaz de promover transformação social. Isso não acontecerá no caso dos conservadores porque eles reproduzem um discurso que impede a mobilização política em torno da questão racial. Progressistas dificilmente conseguirão alcançar esse resultado porque não estão cientes da complexidade da pauta política que defendem. Na verdade, os argumentos desses juristas têm um ponto em comum: todos eles partem do pressuposto de que o processo de argumentação jurídica possui um caráter lógico que deve ser impermeável às experiências dos indivíduos. Esses juristas reproduzem mitos que têm uma natureza política e que, portanto, atuam como mecanismos de reprodução do poder. A defesa da noção de objetividade e imparcialidade é um deles, embora tenha sido rejeitada por filósofos do direito. A epistemologia jurídica tradicional espera que traços da identidade dos juristas não desempenhe qualquer papel dentro do tipo de interpretação que eles fazem.

Mas qual é a função daqueles juristas negros que conseguem chegar a posições que podem influenciar a formação e a reflexão sobre o Direito? Bem, creio que não podemos deixar de reconhecer que a raça tem uma função importante na interpretação das normas jurídicas. Pensar como um negro significa reconhecer que os parâmetros interpretativos de normas jurídicas precisam ser postos a partir de uma determinada perspectiva. Ela está claramente expressa na forma de racionalidade que informa o atual paradigma constitucional. Sei que o princípio da igualdade pode ser interpretado de várias maneiras, mas ele claramente tem o objetivo de promover a emancipação social. Afinal, o próprio constituinte estabeleceu a construção de uma sociedade igualitária como um propósito político central. Isso não poderia ser alcançado sem atribuir ao Estado o papel de um agente de transformação, perspectiva ignorada pelos juristas brancos que defendem o tratamento simétrico como forma de justiça social (KLARE, 1998; LANGA, 1996).

\section{QUAL É O LUGAR DA RAÇA NA INTERPRETAÇÃO JURÍDICA?}

Obviamente, pensar como um jurista negro significa também significa reconhecer que a raça tem um papel central na vida das pessoas. Quero dizer que ela é algo de extrema relevância para negros e para brancos, embora tenha consequências distintas para essas pessoas. Rejeito por completo a ideia segundo a qual a raça é uma mera característica biológica sem implicações na vida dos cidadãos ${ }^{15}$. Não posso deixar de repetir que essa posição tem sido usada para encobrir a opressão aos negros e o privilégio branco, os dois fatores principais para a reprodução da desigualdade racial no Brasil. Pessoas negras e brancas têm uma existência concreta, porém elas também são produtos de ideias que surgiram em um momento no qual europeus precisavam

\footnotetext{
15 BRASIL. Tribunal de Justiça do Espírito Santo. Agravo de Instrumento No 04789000146, Órgão Julgador: $4^{\text {a }}$. Câmara Cível, Relator: Carlos Roberto Mignone, 170.02.2009 (argumentando que a adoção de ações afirmativas deve observar a utilização de critérios justificáveis para que possam estar em acordo com a igualdade, o que não inclui a raça das pessoas em concursos para cargos públicos); TJSC, Arguição de Inconstitucionalidade No. 2005.021645-7/0001.00, Órgão Julgador: Tribunal Pleno, Relator: Luiz César Medeiros, 27/09/2007 (declarando a inconstitucionalidade de um programa de ações afirmativas em curso superior porque o princípio da igualdade não admite a utilização de critério que viole o ideal da universalidade das normas jurídicas); BRASIL. Tribunal Regional da 5a. Região. Agravo de Instrumento 61893, Órgão Julgador: 3ª Turma, Relator: Paulo Gadelha, 24.08.2006 (“A utilização da cor da raça, como critério diferenciador para o acesso a vagas nas universidades, constitui critério de segregação racial e, talvez, o mais indicado para reduzir estas diferenças seja o investimento na qualidade do ensino público, pois, este critério ajudaria não só os estudantes negros, mas, sim, todos os estudantes carentes do Brasil, independente, de raça, sexo ou religião.”)
}

Revista de Direito Brasileira | São Paulo, SP | v. 18 | n. 7 | p. 393 - 421 |Set./Dez. 2017 
justificar diferentes aspectos de projeto colonial que então se desenhava. Eles criaram uma série teorias que tinham o objetivo de afirmar a suposta inferioridade essencial de todos os outros grupos humanos. Essa representação de africanos como pessoas que são essencialmente diferentes traçou as bases das representações culturais que muitas pessoas brancas possuem sobre as pessoas negras até o mundo de hoje.

Mas é claro que as pessoas negras possuem uma existência concreta. Ao contrário do que o professor conservador acredita, a discriminação racial não desaparece na estrutura de classes. Ela é um produto direto das representações sociais que determinam os lugares que pessoas negras devem ocupar dentro da sociedade. Há, por esse motivo, uma relação estrutural entre as desigualdades de status cultural e as desigualdades de status material. Eu posso estar em uma posição social superior à maioria das pessoas negras, mas ainda faço parte de um grupo que não possui o mesmo nível de estima social que os membros do grupo racial dominante gozam. É por esse motivo que negros estão sempre em uma situação social inferior a brancos, mesmo quando possuem o mesmo nível educacional ${ }^{16}$. Muitas pessoas menos qualificadas do que eu encontram-se em uma situação financeira melhor do que a minha. Sei que sou parcialmente culpado por isso. Afinal, vivo escrevendo textos que defendem direitos de minorias raciais e sexuais. Péssima escolha, não é mesmo? De qualquer modo, não podemos esquecer que os mecanismos de exclusão operam a partir da ação conjunta de diferentes sistemas de opressão, motivo pelo qual não devemos nunca pensar que negros são discriminados apenas em função da raça ou de classe.

Disse, há pouco, que os juristas que negam a relevância social da raça obviamente ignoram o fato que ela tem um papel central na vida de pessoas brancas. Ela marca o lugar social delas e esse lugar é a acumulação de privilégios decorrente do pertencimento ao grupo racial majoritário. Juristas brancos não se classificam racialmente. Eles são apenas pessoas, eles são apenas indivíduos. É difícil perceber a discriminação quando a cor da pele não levanta dúvidas sobre sua integridade moral. Aliás, ela aparece como a personificação da superioridade moral, pois todas as representações culturais da integridade pessoal são brancas. Por que uma pessoa branca acharia que a raça tem relevância na vida delas? Afinal, elas nunca foram seguidas em shopping centers, uma experiência pessoal constante. Ser branco dentro da nossa sociedade não marca um lugar social específico, marca uma referência cultural a partir da qual todas as pessoas são julgadas ${ }^{17}$. É por isso que muitos autores dizem que ser branco é um lugar de transparência

\footnotetext{
${ }^{16}$ Ver nesse sentido BRASIL. Supremo Tribunal Federal, Arguição de Descumprimento de Preceito Fundamental No. 186, Órgão Julgador: Tribunal Pleno, Relator: Ricardo Lewandowiski, 26.04.2012 (afirmando que negros estão em situação inferior a negros em inúmeros aspectos da vida social, mesmo quando têm a mesma formação profissional do que brancos); BRASIL. Tribunal de Justiça do Mato Grosso, Apelação Cível No. 2009.003055-0, Órgão Julgador: 4a . Turma Cível, Relator: Paschoal Carmelo Leandro, 19.04.2009 (“Assim, não se vislumbra a alegada inconstitucionalidade das normas legais atacadas pela impetrante, justamente porque a reserva de vagas para negros e índios em universidades públicas se constitui em uma ação afirmativa, que tem por escopo a concretização do princípio da isonomia em seu aspecto material, tendo em vista o real conteúdo e profundidade do postulado constitucional."); BRASIL. Tribunal de Justiça do Rio de Janeiro, Representação por Inconstitucionalidade No. 9/2009, Órgão Julgador: Órgão Especial, Relator: Sérgio Cavalieri Filho (A denominada isonomia formal não leva em conta a existência de grupos, classes de indivíduos ou categorias que necessitam de uma proteção especial para que alcancem a isonomia material. Isso só pode ser realizado através de leis específicas, como o Código de Defesa do Consumidor que protege o consumidor, o Estatuto do Idoso, as leis que estabelecem reservas de vagas para os portadores de deficiência em concursos públicos etc, visando à supressão das diferenças e desigualdades próprias de cada grupo ou classe de indivíduos. E assim é porque a igualdade somente pode ser verificada entre pessoas que se encontram em situação equivalente, sendo levados em consideração os fatores ditados pela realidade econômica, social e cultural."

${ }^{17}$ Ver nesse sentido BRASIL. Supremo Tribunal Federal, Arguição de Descumprimento de Preceito Fundamental No. 186, Órgão Julgador: Tribunal Pleno, Relator: Ricardo Lewandowiski, 26.04.2012 (reconhecendo a existência de um padrão cultural que estabelece preferência para aqueles classificados como brancos no mercado de trabalho); BRASIL. Tribunal Regional do Trabalho da $1^{\mathrm{a}}$ Região, Recurso Ordinário No 0100523-20.2016.5.01.0062, Órgão Revista de Direito Brasileira | São Paulo, SP | v. 18 | n. 7 | p. 393 - 421 | Set./Dez. 2017
} 
total porque não há sentido em se classificar racialmente quando a pessoa é a referência cultural (FLAGG, 1991; OWEN, 2006). É então curioso quando juristas brancos progressistas e conservadores defendem a noção de meritocracia como um parâmetro a ser seguido pelas instituições públicas e privadas. Os homens brancos heterossexuais de classe média alta que participavam do debate sobre ações afirmativas obviamente não reconhecem que o processo de seleção pelo qual passaram começa com a exclusão prévia daqueles sujeitos sociais subordinados. Primeiro os negros, depois as mulheres, depois homossexuais, depois deficientes físicos, depois obesos, depois os pobres (LIPPERT-RASMJUSSEN, 2014). A consideração da meritocracia só começa quando todos os outros grupos indesejáveis já foram eliminados. Mas esses juristas brancos sempre pensam que todas as pessoas têm a mesma experiência social que deles.

É interessante perceber como a minha própria percepção do que seja raça mudou ao longo da minha vida. Sim, tive vontade de ser branco quando era criança porque pensava que as indignidades que sofria decorriam do desprezo social generalizado por pessoas com o tom da milha pele. Nunca cheguei ao ponto de tomar banho com água sanitária como algumas meninas negras do bairro no qual morava. Pensava em alternativas ainda mais radicais como nascer de novo, ser filho de pais brancos. Mais tarde percebi de forma clara que a raça é uma marca de poder. Ela situa as pessoas em lugares distintos dentro da hierarquia social, um sistema inteiramente baseado na possibilidade que um grupo tem de criar e atribuir sentidos a determinadas coisas. Se de um lado eu tinha vergonha de ter rejeitado meu pertencimento à comunidade negra, de outro eu comecei a rir de colegas de classe que me chamavam de preto por se sentirem humilhados ao verem uma pessoa negra mais capaz do que eles. Eu olhava para eles com olhar altivo e tirava uma nota ainda melhor no bimestre seguinte. Todavia, eu compreendo a atitude deles. Isso é inadmissível dentro de uma sociedade construída em torno do privilégio racial, motivo pelo qual percebi que a raça não é nada mais do que uma relação de poder, um marcador de privilégios e de desvantagens materiais. Ninguém nasce negro ou branco. As pessoas são incluídas dentro de um sistema de classificação racial. Porém, elas estão localizadas em lugares distintos dentro da sistemas hierárquicos de um país no qual a raça é uma categoria histórica central. Ela tem sido um dos principais elementos a partir dos quais políticas públicas foram criadas; ela continua sendo uma forma de se possuir vantagens dentro da sociedade ${ }^{18}$.

Muitas pessoas brancas pensam que a raça não tem relevância na nossa sociedade, que a raça nunca teve qualquer papel na vida delas. Sim, ela nunca foi utilizada para impedir que elas tivessem acesso a oportunidades. Afinal, ela é a marca daqueles que são sistematicamente beneficiados pelos arranjos institucionais existentes. Como o privilégio racial é algo muitas vezes invisível para os seus beneficiários, várias pessoas brancas imediatamente condenam mudanças nos arranjos institucionais que lhes garantem as mais diversas vantagens. Os que dizem não ser racistas facilmente se voltam contra políticas sociais que modificam as prioridades estatais, prioridades que sempre tiveram como foco os interesses das classes dominantes, que também são os grupos raciais dominantes. O fato que quase todas as instituições públicas e privadas são moldadas para atender seus interesses materiais não aparece como um problema. A divisão racial do trabalho, a divisão racial da academia, a divisão racial da política, a divisão racial dos meios de comunicação não são problemas porque tudo isso aparece como o funcionamento normal da sociedade. Mas o senso de posição de grupo, a percepção de que o status coletivo pode ser

Julgador: $1^{\text {a }}$. Turma, Relator: Márcia Regina Leal Campos, 14.02.2017 (condenando empresa que obrigava candidata negra a alisar o cabelo para seguir os padrões da moda).

${ }^{18}$ Ver nesse sentido BRASIL. Supremo Tribunal Federal, Arguição de Descumprimento de Preceito Fundamental No. 186, Órgão Julgador: Tribunal Pleno, Relator: Ricardo Lewandowiski, 26.04.2012 (reconhecendo que a raça não tem validade científica, mas possui uma influência negativa real na vida das pessoas); BRASIL. Tribunal de Justiça do Rio de Janeiro, Apelação Cível No. 2005.0001.23440, Órgão Julgador: 8a . Câmara Cível, Relator: Odete Knack de Souza, 17.03.2006 (classificando ações afirmativas como medidas legítimas destinadas a melhorar as condições de vida de pessoas que vivem em condições desiguais devido a diferentes fatores de discriminação.)

Revista de Direito Brasileira | São Paulo, SP | v. 18 | n. 7 | p. 393 - 421 |Set./Dez. 2017 
modificado, surge no momento no qual um governo reconhece essas divisões e toma iniciativas para fazer com que elas desapareçam (BLUMER, 1958). Pessoas brancas vão às ruas vestidas de verde e amarelo e dizem que querem o país delas de volta e, com isso, elas querem fazer referência aos mesmos arranjos econômicos e políticos que protegem os interesses brancos.

Se a raça é uma marca de poder, ela deve ser então compreendida a partir das relações sociais que a estruturam. Seus sentidos podem ser interpretados por meio da análise das determinações históricas a partir das quais suas significações emergem. Essa é uma das premissas que estão por trás da noção de projeto racial: devemos nos perguntar quais foram as condições históricas e sociais responsáveis pelo surgimento dos processos que possibilitaram a racialização de certos grupos em determinadas sociedades e em determinados momentos históricos. Não podemos falar sobre o racismo como um fenômeno que assume as mesmas formas em todos os tempos e lugares. Devemos falar sobre as estratégias criadas em diferentes momentos e lugares para a preservação da dominação racial (OMI; WINANT, 2014, p. 103 - 159) Acho essa perspectiva interessante porque ela abre espaço para pensarmos a raça como uma espécie de texto que adquire sentido dentro de um conjunto de contextos culturais e políticos. Isso nos mostra sua relevância para um jurista que pensa como um negro: a pergunta pelo seu lugar no mundo não é apenas uma forma de interpretação, mas uma determinação de sua própria existência. Se o jurista negro está inserido dentro de um horizonte histórico específico, também a sua raça adquire sentido dentro de uma compreensão historicamente determinada.

O jurista negro compreende a si mesmo e sua raça como elementos que possuem uma historicidade. $\mathrm{O}$ ato de interpretação significa integrar essas duas instâncias dentro de uma perspectiva única. Assim, se a raça é um objeto de interpretação que adquire sentido a partir de sua historicidade, ela não pode ser pensada apenas como uma categoria biológica. A raça não é uma realidade que nasce com um indivíduo. Ela é um tipo de construção social que adquire significação dentro de uma continuidade histórica que demonstra as formas de dominação utilizadas para a reprodução de arranjos sociais. É por esse motivo que um jurista negro precisa estar atento às variações de discursos produzidas em torno da raça ao longo do tempo. Disso depende o desvelamento da sua própria condição de sujeito social. É a partir desses pressupostos que um jurista que pensa como um negro deve interpretar a igualdade: ela não é um princípio que possui o mesmo sentido em qualquer contexto. A sua possibilidade de realização requer a consideração da situação histórica na qual sujeitos concretos se encontram (GADAMER, 1999, p. 400 - 554).

A compreensão da raça como uma categoria biológica demonstra que vários juristas brancos a interpretam como uma característica meramente formal; ela não possui relevância na vida social das pessoas, motivo pelo qual não deve ser parâmetro de aplicação de políticas públicas. Uma das estratégias discursivas que juristas brancos e pesquisadores brancos encontraram em tempos recentes é a representação do brasileiro como um produto de diferentes grupos genéticos. Isso tornaria impossível a utilização da raça como um critério de tratamento diferenciado porque uma pessoa negra pode ter mais genes europeus do que uma pessoa classificada como branca (SANTOS; MAIO, 2004; PENA; BORTOLINI, 2004; KAUFMMAN, 2005). É. Isso realmente parece fazer sentido. Não creio que as mulheres brancas que seguram as suas bolsas quando entro no elevador estejam interessadas em saber qual é a minha herança genética. Minha raça está investida de sentidos culturais que transcendem a minha ascendência. Mas esse uso retórico dela permite que as pessoas não a percebam como uma relação de poder.

Pude realizar alguns anos atrás um dos grandes sonhos da minha vida: visitar as ruínas de grandes civilizações mesoamericanas. Planejei essa viagem por mais de uma década. Nunca me senti tão feliz quando entrei no avião em direção ao México. Estava realmente eufórico. Um senhor negro sentou ao meu lado e começamos a conversar. Descobri após algum tempo que ele é um advogado extremamente bem sucedido. Ele perguntou o que eu fazia e eu disse que era um doutorando. Expliquei o tema da minha pesquisa, o que não o interessou muito. Aquele senhor 
afirmou que não se pode dizer que o racismo afeta a vida de todas as pessoas, não se pode afirmar que ele está em todos os lugares. Além disso, ele também disse que ações afirmativas lançam dúvidas sobre a competência de todos os negros, inclusive daqueles que conseguiram chegar lá por seus próprios méritos. É interessante perceber como a classe social faz com que as pessoas experienciam a raça de formas inteiramente distintas. Para esse indivíduo, sua raça é apenas fonte de alguns pequenos aborrecimentos como, por exemplo, a descrença expressa por algumas pessoas brancas sobre a sua atividade e qualificação profissional. Para negros pobres, a raça é uma fonte constante de vulnerabilidade econômica, pois é o principal motivo pelo qual eles estão nessa situação.

A classe social faz com que as pessoas não percebam que a exclusão social decorre de uma soma de fatores, motivo pelo qual alguns afirmam que sujeitos subalternos são sujeitos interseccionais. Nós negros não somos excluídos apenas em função de classe social, mas também em função da raça. Outros estão em uma situação ainda mais problemática porque também são desprezados em função do sexo e da orientação sexual. Portanto, um jurista que pensa como um negro não pode compreender a exclusão do povo negro como um problema decorrente apenas de classe social porque essa comunidade possui uma grande variedade de sujeitos e eles estão expostos a diversas formas de opressão. A raça é um elemento que opera ao lado de outros fatores de exclusão: mulheres negras vivenciam a raça de forma distinta de homens negros, negros homossexuais têm uma experiência racial distinta de negros heterossexuais. Esse é o motivo pelo qual a mente de um jurista que pensa com um negro deve ser uma forma de consciência múltipla: ele precisa estar atento aos diversos fatores que determinam as experiências de grupos subalternos. Ele não pode pensar a partir de uma única perspectiva porque isso impede o reconhecimento da diversidade de experiências e formas de opressão que convergem para reproduzir a estratificação social (CRENSHAW, 1989).

\section{O HUMANISMO RACIAL BRASILEIRO: O NOSSO RACISMO PARTICULAR}

Eu comecei a procurar estágios no quarto ano da faculdade; tinha sido bolsista de uma agência federal de fomento à pesquisa até aquele momento. Era um bom aluno, minha pesquisa tinha ganhado o prêmio de melhor trabalho na área de ciências sociais aplicadas no ano anterior no âmbito da universidade na qual estudava. Procurar trabalho não foi nada fácil. Sempre via colegas brancos conseguindo estágios em lugares que tinham acabado de me informar que todas as vagas tinham sido preenchidas. Não preciso dizer que estava muito frustrado com essa situação. Mais do que isso. Estava furioso e indignado, mas minhas reclamações não encontravam ressonância entre meus colegas e professores brancos. Lembro-me da reação deles em uma discussão de uma obra sociológica clássica, $O$ povo brasileiro. O autor exalta a propensão dos brasileiros à miscigenação, o que teria feito de nós um povo que preza a harmonia social. Eu intervi e disse não existir no mundo pessoas mais racistas do que os brasileiros. $\mathrm{O}$ protesto foi geral. Nem mesmo a citação de inúmeras estatísticas foi suficiente para convencer os colegas brancos (a outra pessoa negra presente me disse depois que eu não estava ganhando nada confrontando aquelas pessoas com provas de racismo generalizado). Elas também se recusaram a reconhecer que a minha experiência de racismo no mercado de trabalho representa uma prática social comum no Brasil. Alguns alunos que tinham estagiado nessas instituições disseram que isso era uma simples consequência da melhor formação dos outros candidatos. Mas quantos deles ganharam os mesmos prêmios que eu?

Uma das coisas que mais me deixa perplexo é a recusa de juristas brancos em reconhecer a existência e a extensão da forma como o racismo opera no Brasil. Eles utilizam duas estratégias para negar a relevância desse sistema de opressão social entre nós, as mesmas utilizadas pelos meus colegas de faculdade no episódio acima citado. Alguns fazem referência à suposta superioridade moral dos brasileiros em relação a outros povos. Eles alegam que esse 
problema não existe entre nós, posição decorrente da compreensão do racismo como um sistema de discriminação legalmente sancionado ${ }^{19}$. Outros argumentam que eventuais manifestações racistas não expressam um problema estrutural, mas apenas preconceito de classe, o que não compromete a afirmação de que temos uma cultura pública baseada na harmonia racial. Alguns admitem que o racismo existe na nossa sociedade e que é praticado em alguma escala, mas também se recusam a reconhecer que ele possui uma dimensão coletiva e sistêmica. A compreensão do racismo de muitos juristas brancos se limita ao problema do preconceito, o que pode ser eliminado com a afirmação de uma cultura pública da igualdade ${ }^{20}$.

Não posso deixar de reconhecer que algumas dimensões das teses defendidas por esses indivíduos são realmente atraentes. A percepção de que vivo em uma sociedade que está calcada na exclusão racial é algo que me cansa fisica e mentalmente. Aliás, eu vivo em uma situação de constante exaustão mental. Seria mesmo ótimo se tivéssemos uma cultura pública baseada no respeito entre grupos raciais. Seria ótimo viver em um país no qual a transcendência racial fosse uma realidade. Ficaria mais feliz ainda se o problema do racismo pudesse ser resolvido a partir de uma mudança cognitiva das pessoas. O problema fundamental dessas posições está no fato que o racismo opera independentemente de motivação pessoal. Práticas institucionais podem não ser implementadas com o objetivo de prejudicar negros, mas elas podem ter um impacto desproporcional para essa coletividade. Há outros problemas. Pessoas brancas não discriminam pessoas negras apenas em função de estereótipos negativos. Elas têm um interesse material no racismo. Todas as pessoas brancas estão cientes que ser branco traz vantagens materiais, motivo pelo qual elas fazem todo o possível para que esses privilégios permaneçam nas mãos de pessoas brancas. Uma educação iluminista não modificará essa realidade (LIPSITZ, 2006).

As pessoas não discriminam apenas porque têm uma compreensão falsa do outro. As pessoas discriminam porque elas estão comprometidas com um sistema de privilégio social desenhado para garantir a permanência de vantagens materiais nas mãos do grupo racial dominante. Outro dia estava lendo uma decisão judicial na qual uma mulher negra processava uma mulher branca por danos morais. Essa última teria dito que ela não conseguiria as mesmas oportunidades profissionais que uma mulher loira conseguiria. Bem, ela está certa. Pessoas brancas estão cientes que o pertencimento ao grupo racial dominante traz benefícios materiais e muitas delas fazem o possível para que eles permaneçam nas mãos de pessoas brancas. Elas sabem que ser branco é uma fonte de recompensas materiais e por isso elas têm um interesse na branquitude. Não podemos então acreditar nesse discurso que aborda o racismo a partir dos pressupostos do liberalismo. É curioso perceber que os problemas são colocados apenas como uma questão de irracionalidade, o que está longe de ser verdade. O maior problema do racismo não decorre apenas do fato que ele desvirtua os princípios de uma sociedade liberal. Na verdade, o problema com o racismo é que ele nunca permitiu que essa sociedade existisse (FITZPATRIC, 1987; MILLS, 1999)

\footnotetext{
${ }^{19}$ Ver nesse sentido BRASIL. Tribunal Regional Federal da 5a . Região, Apelação Cível No. 513491, Órgão Julgador: $2^{\mathrm{a}}$. Turma, Relator: Francisco Wildo ("porque a política da adoção de quotas raciais, para aprovação no concurso vestibular era um tremendo equívoco porque, como afirmava - entre outros - o professor Inácio Strieder, professor de Ciências Humanas na Universidade Federal de Pernambuco, "a situação dos Estados Unidos era diversa da existente no Brasil", considerando que o Brasil é formado por ser um povo mestiço por excelência, desde quando os descendentes lusos - e portanto, brancos - lutaram, lado a lado, com os descendentes de negros e de índios, para libertar a colônia do jugo holandês."); BRASIL. Tribunal de Justiça do Rio de Janeiro. Ação Direta de Inconstitucionalidade No. 0009/2009, Órgão Julgador: Órgão Especial, Relator: José Carlos S. Murta Ribeiro, 25.05.2009 (argumentando que ações afirmativas criam um apartheid social no Brasil, o que seria contrário a uma sociedade baseada na harmonia social entre as raças).

${ }^{20}$ Ver, por exemplo, BRASIL. Supremo Tribunal Federal. Arguição de Descumprimento de Preceito Fundamental No. 186-2, Relator: Gilmar Mendes, 29. 07.2009 (apontando a diferença de moralidade pública entre o Brasil e os Estados Unidos); TJES, Apelação Cível No. 024070612809, Órgão Julgador: 4a. Câmara Cível, Voto: Maurílio Almeida de Abreu, 15/12/2009 (reconhecendo que ações racistas existem no Brasil, mas dizendo que eles não implicam uma cultura da desigualdade).
}

Revista de Direito Brasileira | São Paulo, SP | v. 18 | n. 7 | p. 393 - 421 | Set./Dez. 2017 
O racismo opera de forma institucional e sistêmica. Já disse que pessoas brancas controlam praticamente todas as instituições públicas e privadas deste país; isso permite que elas operem de acordo com os interesses do grupo racial dominante. Mais do que isso, essas instituições não atuam de forma isolada. As mesmas motivações que informam a operação de uma também informam a operação de outras. O racismo que torna a escola um ambiente hostil para crianças também motiva o comportamento discriminatório de policiais militares em relação a negros que também influencia a forma como negros são tratados no sistema judiciário. Por ser uma prática coletiva, ele informa o funcionamento de instituições públicas e privadas, afetando diversas dimensões das vidas de pessoas negras neste país (NASCIMENTO; NASCIMENTO, p. 105 - 146).

Minha experiência dentro de sala de aula serve de exemplo para examinar outro ponto importante da discussão sobre formas de interpretar o mundo. Mais uma vez discutia o tema de inclusão racial em uma aula sobre direitos humanos. Muitos alunos brancos argumentaram que não é possível construir uma sociedade igualitária a partir de política que separam as pessoas. Um aluno negro perguntou a um deles como seria possível construir essa sociedade com toda a desigualdade existente, desigualdade causada por membros dos grupos que criticam essas medidas. Uma aluna branca disse que não tinha conhecimento de coisas que pessoas brancas fizeram que justifiquem a discriminação delas no atual momento histórico. $O$ aluno negro perguntou se ela já tinha ouvido falar sobre a escravidão africana. A aluna disse que esse fato histórico não tinha mais consequências no mundo atual. $\mathrm{O}$ aluno negro, aparentemente desestimulado em discutir com alguém que se recusa a reconhecer a relevância da história, permaneceu em silêncio.

Penso que essas posições apresentam um problema chave desse debate: a afirmação da inocência branca. Negar o racismo ou concebê-lo como um problema comportamental impede que as pessoas tomem consciência de que práticas de exclusão racial indiretamente beneficiam todas as pessoas brancas. Juristas brancos, ao negarem a relevância do racismo, criam um mundo social imaginário no qual as atrocidades cometidas no passado não guardam nenhuma relação com a realidade presente. A celebração da nossa suposta superioridade moral em relação a outras nações permite que os processos de estratificação racial não sejam reconhecidos e questionados. As formas como as instituições sociais operam para manter os privilégios raciais também não podem ser abordados, mesmo porque eles não existem; tudo do que foi alcançado por pessoas brancas não são nada mais do que produto do próprio esforço. Juristas brancos progressistas igualmente permitem que a inocência branca seja perpetuada porque também não questionam o privilégio. Não há como construir uma agenda emancipatória sem o reconhecimento das relações entre o privilégio e a opressão (MOREIRA, 2013; HUNT, 2005).

Estou escrevendo esta parte deste artigo depois de ter assistido um documentário sobre a história de líderes da luta pelos direitos civis dos negros norte-americanos contada por James Baldwin. Em certo momento, ele utiliza o termo apatia moral para caracterizar a atitude da população branca daquele país, grupo que se recusa a admitir o fato de que a opressão negra é produto direto do privilégio branco. $\mathrm{O}$ discurso do progresso racial aparece para escamotear o fato de que a justiça racial é algo que está longe de ser realizado e que talvez nunca seja alcançado por causa do aspecto estrutural do racismo. $\mathrm{O}$ discurso da neutralidade racial atua para encobrir o fato de que o racismo é o principal problema político daquela nação. $\mathrm{O}$ mesmo mecanismo opera entre nós e é por esse motivo que compreendo o suposto humanismo racial brasileiro como um projeto de dominação racial. Ele serve para impedir o reconhecimento da ação pervasiva do racismo na nossa sociedade por meio da reprodução de uma epistemologia social que mascara o seu aspecto estrutural. O humanismo racial brasileiro está estruturado em cima da premissa de que nós criamos uma cultura pública caracterizada pelo reconhecimento da importância das diferentes heranças culturais na formação da identidade individual e coletiva. Se de um lado princípios liberais permitem a afirmação do valor indivíduo, a nossa miscigenação 
magnifica a integração social. Basta então a implementação de políticas sociais universais para que brasileiros de todas as raças possam ser integrados. É curioso perceber que muitos intelectuais brancos recorrem a estudos científicos para corroborar a tese sociológica da relevância do hibridismo na interpretação das normas jurídicas. Eles asseveram que as descobertas científicas justificam políticas públicas universais porque cada brasileiro é produto de diversos grupos raciais. Se a raça não tem relevância entre nós, ela não pode ser utilizada como parâmetro para políticas públicas (MAGGIE, 2005; FRY, 2000). Mas eles não são os únicos. Juristas brancos seguem o mesmo modelo de pensamento ao enfatizar a nossa suposta natureza híbrida ${ }^{21}$.

Um jurista que pensa como um negro precisa basear sua reflexão em uma epistemologia que reconheça a natureza dinâmica do racismo. O suposto humanismo racial que vigora entre nós impede a percepção desse aspecto no sistema de opressão porque ele surge dentro dessa retórica apenas como um comportamento irracional. Ele expressa preconceitos que estão calcados em estereótipos, o que permite afirmar que ele tem um aspecto basicamente cognitivo. Um jurista que pensa como um negro não pode deixar se seduzir por uma mera explicação comportamental do racismo porque ele é muito mais do que isso. O racismo é antes de tudo um projeto de dominação que pode assumir diversas formas em diferentes sociedades e em diferentes momentos históricos. O tipo de epistemologia social presente no humanismo racial brasileiro classifica o racismo como algo que existe apenas no plano individual; ele não possui um caráter sistêmico. Por esse motivo, ele não teria relevância no Brasil porque possíveis atos racistas, se existirem, podem ser corrigidos pelas normas penais. É curioso então que o projeto racial brasileiro reconheça a relevância do racismo no âmbito penal, mas nega a sua importância no campo do direito público. ${ }^{22}$

Não sou o primeiro a dizer que a mitologia da democracia racial brasileira é um tipo de liberalismo racial. Essa ideologia é uma narrativa que permite apenas a pessoas brancas serem reconhecidas como agentes capazes de atuar na vida pública. Isso acontece porque a defesa do universalismo permite que as formas estruturais de exclusão continuem reproduzindo a estratificação racial ao mesmo tempo que defende o tratamento igualitário como a única forma de justiça racial. É assim que a ideologia da democracia racial opera: ela atribui as disparidades entre negros e brancos a questões de classe social, o que legitima a afirmação das nossas elites brancas como grupos comprometidos com princípios liberais. Dentro desse raciocínio, a nossa miscigenação possibilita o pleno funcionamento de princípios liberais em função da nossa homogeneidade racial, elemento importante para a criação de uma cultura pública comum. Essa era a premissa básica por trás da afirmação de que eu não represento a situação da população negra porque minha titulação demonstra que o racismo não afetou minhas chances de ascensão social. O humanismo racial brasileiro articula princípios liberais com a ideologia da democracia racial para negar a necessidade de políticas de inclusão racialmente conscientes no Brasil. Assim, as promessas de transformação presentes na Constituição Federal são destituídas de efeito e os

\footnotetext{
${ }^{21}$ Ver nesse sentido BRASIL. Tribunal de Justiça do Rio de Janeiro. Ação Direta de Inconstitucionalidade No. 0009/2009, Órgão Julgador: Órgão Especial, Relator: José Carlos S. Murta Ribeiro, 25.05.2009 (alegando que o Brasil possui uma cultura pública de tratamento igualitário entre grupos sociais); BRASIL. Tribunal Regional do Trabalho da 10 $0^{\mathrm{a}}$ Região, Recurso Ordinário No 00936-2005-012-10-00-9, Órgão Julgador: 1 $1^{\mathrm{a}}$. Turma, Relator: Oswaldo Florência Neme Júnior, 21.03.2007 (indeferindo pedido de adoção de ações afirmativas em bancos privados sob o argumento que construímos uma cultura pública distinta de outros países).

${ }^{22}$ Ver nesse sentido, BRASIL. Supremo Tribunal Federal, Medida Cautelar em Arguição de Descumprimento de Preceito Fundamental No. 186-2, Relator: Gilmar Mendes, 31/07/2009 (argumentando que o Brasil viveu um processo de miscigenação, o que torna problemática a criação de políticas públicas baseadas na raça dos indivíduos); BRASIL. Tribunal Regional Federal da 1a. Região, Agravo de Instrumento No. 61893, Órgão Julgador: $2^{a}$. Turma, Relator: Paulo Gadelha, DJ 27/01/2006 (afirmando que a presença de africanos, europeus e ameríndios criou a presença de uma sociedade altamente miscigenada, o que cria grandes dificuldades para a classificação de indivíduos segundo critérios raciais).
} 
mecanismos de exclusão continuam atuando para perpetuar uma ordem social construída para privilegiar pessoas brancas desde a sua fundação.

Afinal, o que um jurista negro deve pensar o racismo? Em primeiro lugar ele deve estar ciente de que a igualdade racial é um ideal difícil de ser alcançado em uma sociedade na qual os membros do grupo racial dominante controlam todas as decisões políticas. Não podemos esquecer que o racismo é um elemento central da operação de instituições públicas e privadas e que uma parte significativa das pessoas brancas fará todo o possível para manter seus privilégios raciais. O racismo é uma ideologia e uma prática de caráter permanente. Isso significa que ele sempre assumirá novas formas para que o poder do grupo racial dominante seja mantido. Nossas possíveis vitórias terão sempre um caráter temporário e precário, motivo pelo qual a luta do povo negro não terá fim. As transformações do status legal dos negros brasileiros demonstram isso de forma clara: cada nova conquista de direitos foi acompanhada pela rearticulação de uma nova ideologia que tinha o propósito de manter privilégios raciais. Políticas imigratórias foram implementadas para promover o branqueamento da nação e práticas higienistas foram criadas para limitar a atuação social de negros após a abolição. As elites brasileiras formularam a imagem do Brasil como uma democracia racial para impedir a mobilização política em torno da raça, e agora temos uma rearticulação dessa ideologia para coibir a expansão de políticas de inclusão racial. Assim, devemos estar cientes que sempre haverá uma luta para que a condição de subordinação do povo negro seja sempre mantida.

\section{SOBRE A IMPORTÂNCIA DO PROTAGONISMO NEGRO}

Estou terminando de escrever este artigo em uma bela tarde de domingo. O resultado parece interessante; creio que ele terá boas chances de ser aceito para publicação. Olho para a janela e penso que poderia estar no cinema, uma das minhas atividades favoritas. Entretanto, também estou escrevendo este artigo porque penso que quanto maior for o número de publicações nas melhores revistas do país, maiores serão as minhas chances de me afirmar profissionalmente. Negros aprendem desde cedo que vivem dentro de um sistema desenhado para reproduzir o privilégio branco, mesmo de pessoas brancas medíocres. Isso significa que precisamos mostrar um nível de excelência muitas vezes maior para recebermos metade do reconhecimento, sendo que, muitas vezes, não obtemos reconhecimento algum. Estudei em uma escola pública na cidade de Belo Horizonte. Sempre era um dos poucos alunos negros na minha turma. Muitas vezes era o único. O dia de devolução das provas era uma dessas vezes nas quais a pessoa negra percebe que o ambiente escolar é um lugar hostil. Estava na sétima série. Via uma professora sempre exaltar os alunos brancos pelo desempenho nas avaliações, mas ela nunca mencionava o meu nome. Eu levantava, pegava a prova, via a minha nota e perguntava quanto meus colegas tinham conseguido. Algo triste aconteceu em uma dessas vezes que tinha obtido a melhor nota da sala. Um colega branco me perguntou como tinha conseguido a melhor nota da turma com o meu cabelo carrapicho. Toda a sala riu, a professora riu. Fui reclamar com a diretora. A professora disse que o fato não tinha importância. Ela afirmou que não era nada mais do que uma brincadeira. Nada poderia estar mais distante da realidade. Ela nunca mais permitiu que eu respondesse a perguntas, apesar do meu desempenho sempre excelente.

Voltei para casa transtornado com o que tinha acontecido, mas minha tristeza durou pouco, pois minha mãe disse que tinha correspondência para mim. Era um grande envelope marrom e dentro dele havia um prêmio para aqueles que tinham conseguido completar um álbum sobre os membros da Liga da Justiça. Fiquei extasiado! Tinha recebido um cartão e um diploma assinado por aqueles poderosos seres, além de um livreto contando como eles conseguiram suas habilidades sobre-humanas. Confesso que meu entusiasmo com super-heróis diminui muito ao longo dos anos. Um grande amigo branco me convidou para ir ao cinema ver o mais novo filme do super-homem. Disse a ele que estava cansado de ver homens brancos salvando o mundo. 
Minha fala o deixou muito constrangido e eu imediatamente tentei me explicar. Disse que não aguentava mais ver essas representações da suposta superioridade moral de homens brancos. Ele ficou ainda mais chateado e então entrei em uma discussão sobre os motivos pelos quais todos os meios de comunicação deste país passam cotidianamente a mensagem que apenas homens brancos podem ocupar posições de poder e prestígio. Embora isso seja algo invisível para ele, eu vejo as consequências desse problema sempre que entro em sala de aula. A surpresa e o desagrado de certos alunos e alunas com um professor negro é patente. Esse problema também está presente em milhares de decisões judiciais sobre discriminação no mercado de trabalho. $\mathrm{O}$ empregador que pede para a mulher negra alisar o seu cabelo, o empregador que não contrata negros por causa da reação negativa de clientes brancos, o empregador que mantém os funcionários negros em funções que não requerem contato com o público. O que está por trás de todos esses casos é a ideia de que pessoas brancas são um ideal estético, um ideal moral, enfim, o ideal de pessoa, aquelas que podem ser chamadas de seres humanos.

Sou um homem negro e tenho calafrios quando ouço alguém dizer que é conservador, mas sinto a mesma coisa quando encontro alguém que diz ser progressista. Isso pode parecer meio problemático porque alianças com pessoas progressistas são de grande importância para a justiça racial. Tenho ouvido muitas pessoas e instituições advogarem uma agenda progressista. Esse discurso inclui a afirmação de que elas estão antenadas com as questões contemporâneas, que elas fazem o possível para abordar o estudo do Direito de forma crítica, que elas querem formar alunos com uma consciência crítica. Essas propostas parecem ser muito interessantes, porém algo me vem à mente quando examino o corpo de profissionais que trabalham nesses lugares: todos ou quase todos são brancos. Quase todos são homens brancos e presumo que a maioria seja heterossexual. Será mesmo que uma instituição na qual só trabalham representantes do grupo dominante pode realmente ser chamada de inovadora ou progressista? Bem, uma leitura do currículo desses profissionais mostra que a vasta maioria deles nunca escreveu um único trabalho sobre temas relevantes para a agenda progressista. Isso sugere que os alunos dessas instituições ouvirão o mesmo tipo de discurso jurídico presente em outras. Isso não ocorre apenas em faculdades de direito. Quase todos os juízes brasileiros e quase todos os promotores brasileiros são representantes dos grupos majoritários. Os epítetos associados a essas instituições também sugerem que elas estão comprometidas com causas socialmente relevantes. Elas são associadas à justiça, à cidadania, à dignidade, ao desenvolvimento.

Quais são as possíveis consequências da predominância de pessoas brancas e mais particularmente de homens brancos nessas instituições para a busca de justiça racial? Muitos desses profissionais podem estar de fato comprometidos com os ideais acima mencionados, mas podem estar impedidos de atuar da forma mais efetiva em função da perspectiva epistemológica a partir da qual eles operam. O racismo pode assumir uma forma sistêmica porque a discriminação racial é invisível para a quase totalidade das pessoas brancas. Elas podem defender uma forma de funcionamento institucional baseado em princípios de caráter liberal, mas isso compromete o ideal de justiça porque essas instituições não estão equipadas para tratar as questões relacionadas com as vidas de pessoas que têm um pertencimento social distinto de outros indivíduos. Vejam a discussão sobre a preservação de secretarias destinadas à proteção de minorias raciais na cidade de São Paulo. Muitos diziam que a existência delas é uma forma de racismo porque destina recursos públicos a um grupo específico. Eles afirmavam que a possível discriminação sofrida por negros deveria ser combatida pelas instituições já existentes. A retórica do racismo é hoje igualmente utilizada por aqueles que eliminam as instituições destinadas a combater o racismo visto que esses indivíduos alegam que elas promovem o separatismo social.

É interessante perceber como esses argumentos refletem a lógica do opressor. O racismo não é medido a partir da realidade concreta de exclusão social da população negra, mas a partir das formas como essas medidas podem afetar as pessoas brancas. Assim, o que determina a necessidade de existência dessas instituições é o interesse branco. Brancos se sentirão 
segregados, brancos perderão oportunidades, brancos também precisam de proteção estatal. A retórica da inocência branca aparece aqui mais uma vez para legitimar uma ordem social que sempre existiu para reproduzir o privilégio branco. Porém, ele permanece socialmente invisível, o que permite a reprodução da retórica da meritocracia (FREEMAN, 1977, p. 1049 - 1055). Esse argumento da inocência branca está baseada no que algumas pessoas chamam de epistemologia da ignorância. O termo epistemologia está relacionado com as condições adequadas do conhecimento, enquanto o termo ignorância implica a ausência dele. Porém, alguns autores dizem que a ignorância pode ter um caráter estratégico quando ela impede o conhecimento da realidade ou reproduz um tipo de percepção inadequada dos fatos para garantir a manutenção da ordem social (MILLS, 1999, p. 41 - 91). O humanismo racial brasileiro é um exemplo claro dessa epistemologia da ignorância: a realidade de opressão racial é estrategicamente deturpada para encobrir os mecanismos de exclusão racial

Minhas reflexões como um jurista negro me levaram a reconhecer a imensa relevância do protagonismo negro. Não há possibilidade de construção de uma sociedade racialmente justa quando praticamente todas as instituições sociais são controladas por pessoas do mesmo grupo racial. Muitos brancos rejeitam essa tese. Eu me lembro de uma ocasião na qual um colega de faculdade se mostrou profundamente ofendido quando disse que a chapa da qual ele fazia parte não era representativa porque não tinha negros ou mulheres. Ele sentiu aquilo como um ataque pessoal. Sua face ficou vermelha de raiva e senti que ele iria reagir fisicamente. Mas ele se conteve e disse que minha fala não tinha sentido porque a plataforma política procurava defender os interesses de todos os alunos. Perguntei se ele tinha se reunido com os alunos negros da faculdade e perguntado se eles tinham alguma demanda específica. Ele disse que isso não era necessário porque negros não enfrentam problemas específicos enquanto negros naquela instituição. Perguntei a ele como ele classificava o assédio moral sofrido por alunos e alunas homossexuais dentro dessa lógica. Ele sorriu ironicamente. Em função desse comportamento, eu disse que a reação dele era o motivo pelo qual precisávamos de uma chapa mais diversificada.

Embora muitos suspeitem da ideia de diversidade, creio que ela possui alguns elementos particularmente relevantes. Se inicialmente ela era defendida simplesmente porque facilitava a troca de experiências no espaço acadêmico, ela adquiriu depois um aspecto político. A diversidade é uma prática institucional necessária porque permite a representação adequada dos diferentes grupos no processo decisório, algo desejável em sociedades multiculturais. Esse sentido de diversidade é particularmente importante no Brasil porque praticamente todas as instituições públicas e privadas são controladas por homens brancos heterossexuais. Isso não seria problema se eles fossem as pessoas mais competentes para tais postos e se atuassem a partir do interesse de todos. Contudo, sabemos que isso está longe de ser o caso. A preponderância de homens brancos heterossexuais de classe média e de classe alta no controle de instituições públicas e privadas decorre do fato de que eles não estão submetidos a processos de exclusão. Como muitas pessoas compreendem o mundo a partir da própria experiência social, os membros desse grupo apreendem o mundo a partir de uma posição interpretativa que pode ter efeitos racistas (IENSUE; CARVALHO, 2015; ESTLUND, 2005). A ausência de experiências de discriminação produz o fenômeno da transparência: meu colega parte do pressuposto de que todas as pessoas enfrentam os mesmos problemas na vida acadêmica e profissional. A chapa foi eleita e durante o período que eles permaneceram na direção do centro acadêmico questões como discriminação racial e sexual nunca foram abordadas. Eles nunca procuraram saber qual era a experiência das mulheres dentro da faculdade e temas relacionados a orientação sexual não eram nem mesmo considerados um ponto relevante de discussão.

Volto à questão da transparência. Essa pequena história reflete uma moralidade bastante difundida que parte do pressuposto de que algumas pessoas podem representar as outras porque todos nós temos experiências homogêneas. Mas basta começarmos a enumerar os critérios a partir dos quais as pessoas são discriminadas para verificarmos que pessoas brancas não podem 
falar por pessoas negras, homens não podem falar por mulheres, nem heterossexuais podem falar por homossexuais. Esses grupos precisam ter um espaço político assegurado para que possam influenciar decisões políticas. Uma jurista branca disse que esse espaço deve começar dentro das faculdades de direito e eu concordo plenamente com ela nesse aspecto. As faculdades de direito formam pessoas que atuarão em uma série de instituições relevantes, motivo pelo qual as pessoas precisam aprender a pensar como um negro. A diversificação das faculdades de direito é uma necessidade premente para a nossa sociedade porque a vasta maioria delas é composta por pessoas brancas heterossexuais de classe média alta, pessoas que possuem uma perspectiva de interpretação da realidade distante da vasta maioria da população brasileira. O protagonismo negro, o protagonismo feminino, o protagonismo homossexual são de extremamente relevância porque são essas as pessoas que estão primordialmente interessadas em pesquisas sobre as condições sociais que as afetam. Na maioria das vezes, são elas que produzem o conhecimento necessário para a transformação social. ${ }^{23}$

\section{ALGUMAS CONSIDERAÇÕES SOBRE O PRIVILÉGIO}

A primeira pessoa que namorei era branca. Estava no terceiro ano do segundo grau. Tive a felicidade de passar no vestibular; ela não teve a mesma sorte. Um dia tivemos uma discussão que terminou com a seguinte frase: "Você pode ter passado no vestibular, mas eu sou branca!" Jurei nunca mais namorar alguém de outra raça. Entretanto, encontrar uma pessoa negra com a mesma formação intelectual naqueles dias não era nada fácil, e, além disso, há seres humanos e seres humanos. Voltei a namorar outra pessoa branca anos depois. A descoberta de vários interesses em comum fez com que nos aproximássemos. Ela dizia ser inteiramente identificada com a cultura negra e seus gostos musicais, suas roupas e seu cabelo demonstravam isso de certa forma. Nosso relacionamento era ótimo, contudo, certas questões sempre criavam situações conflituosas. Ela achava que eu não era suficientemente identificado com a cultura negra. Meu interesse por ópera, meu desconhecimento das religiões de matriz africana e de escritores negros contemporâneos eram, segundo ela, indicações que eu estava lutando contra o opressor, mas identificado com a cultura dele. Perguntei a essa pessoa se ela achava que eu poderia deixar de me sentir como negro, mesmo que por um segundo, em uma sociedade como a nossa. Perguntei também se ela já tinha sido impedida de ter acesso a alguma oportunidade acadêmica ou profissional em função da cor da pele dela. Também indaguei se a identificação com a cultura negra e o uso de trajes africanos alguma vez foram motivo de discriminação. Ela respondeu que não e eu disse que a fala dela indicava que ela precisava amadurecer um pouco mais para que a luta dela por igualdade pudesse ser alcançada. Não ficamos muito tempo juntos por causa da dificuldade de percepção das diferenças estruturais existentes entre negros e brancos neste país.

Algum tempo atrás li uma reportagem curiosa em um jornal. Falava de um mendigo de uma cidade do sul do Brasil que despertou o sentimento de solidariedade de muitas pessoas. Ele era um belo homem branco de olhos azuis que a imprensa chamou de "mendigo gato". Ver um homem que corresponde ao ideal ariano de beleza que os brasileiros cultuam de forma obsessiva permitiu que esse indivíduo saísse da rua e conseguisse um emprego. Por que as pessoas se sentiram tão comovidas com essa situação? A resposta é óbvia. Elas acham que pessoas brancas não merecem estar em uma situação dessa natureza, principalmente se elas têm olhos azuis.

\footnotetext{
${ }^{23}$ BRASIL. Supremo Tribunal Federal, Ação de Descumprimento de Preceito Fundamental No. 186, Órgão Julgador: Tribunal Pleno, Relator: Ricardo Lewandowiski, 26.04.2012 (afirmando que a noção de diversidade é um parâmetro importante para a interpretação da igualdade porque os diferentes grupos sociais precisam estar igualmente representados nos processos decisórios). ESTADOS UNIDOS. Suprema Corte dos Estados Unidos. Grutter v. Bolinger, 539 U.S. 306, 2003 (argumentando que a diversidade possui uma dimensão material expressa na necessidade de se garantir a presenta de representantes dos diversos grupos sociais nas instituições que tomam decisões que afetam todas os membros da sociedade política).
}

Revista de Direito Brasileira | São Paulo, SP | v. 18 | n. 7 | p. 393 - 421 | Set./Dez. 2017 
Muitos não foram capazes de expressar qualquer empatia com os rapazes negros e pobres que foram assassinados por policiais enquanto voltavam para casa depois da comemoração da conquista de um novo emprego por um deles. Vários disseram que os policiais estavam fazendo o trabalho deles e que aquelas mortes não poderiam ser classificadas como assassinatos. Entretanto, eles se emocionam com o homem branco de olhos azuis que foi parar na rua em função do seu envolvimento com drogas. Obviamente, a raça é o fator que determina a forma como essas pessoas são tratadas, como as pessoas direcionam a empatia. As histórias do mendigo gato e dos meninos negros assassinados mostram que negros e brancos não possuem e nunca possuíram o mesmo apreço social na nossa sociedade. $\mathrm{O}$ respeito pelas pessoas é o parâmetro fundamental a partir do qual oportunidades materiais são distribuídas. Isso significa que a constante reprodução da branquitude como um ideal estético e moral faz com que pessoas brancas estejam sempre sendo privilegiadas e pessoas negras sempre sofrendo desvantagens sociais, mesmo que elas pertençam à mesma classe social.

Estou inteiramente ciente de que a luta contra a opressão racial não pode ser vencida apenas a partir da mobilização das pessoas negras. A justiça racial depende da mobilização de todos os grupos, razão pela qual devemos fazer o possível para criar redes de solidariedade social. Entretanto, devemos ter em mente que as pessoas existem dentro de uma estrutura hierárquica de poder e isso significa que algumas pessoas estão em uma posição permanente de privilégio, enquanto outras estão em uma situação permanente de subjugação. Uma pessoa branca pode assumir uma variedade de identidades dentro da nossa realidade multicultural. Ela tem diante de si uma série de possibilidades de experimentar estilos de vida e ainda manter seus privilégios raciais. Essa oportunidade não está aberta da mesma maneira para aqueles que são marcados socialmente. Meu suposto interesse em querer parecer branco só poderia ser uma forma de falsa consciência. Ao contrário do que aquela pessoa argumentou, estou ciente de todos os sentidos sociais associados à negritude. Ela não tinha compreendido até aquele momento que sua cor da pele a coloca em uma situação de privilégio estrutural em relação a todos os negros, mesmo os que ela julga não ser genuinamente negros. Sei que nunca serei integralmente respeitado como um ser humano em uma sociedade baseada no privilégio branco. Nós negros não temos como fugir disso.

A fala dessa pessoa é interessante porque a eliminação do privilégio branco é um ponto central da luta contra o racismo. Pessoas brancas são beneficiadas pelo racismo, inclusive aquelas que estão engajadas na luta contra esse sistema de opressão. Nunca podemos esquecer que o racismo tem o objetivo de garantir vantagens econômicas para os membros do grupo dominante, motivo pelo qual o simples pertencimento a ele garante acesso a vantagens indevidas. Essas vantagens variam da representação positiva dos membros do grupo racial dominante, o que lhes permite construir uma imagem positiva de si mesmos, até a inexistência de barreiras raciais no mercado de trabalho, o que torna o planejamento da vida pessoal algo muito mais fácil, desde que você não pertença a uma minoria sexual. O privilégio aparece até mesmo dentro das relações pessoais. Essa pessoa que mencionei nunca precisou questionar a sua identidade racial dentro dos relacionamentos porque a raça não é um problema social para ela. Brancos também se beneficiam por serem construídos como o único tipo de parceiro sexual aceitável. Enquanto negros estão desprovidos da segurança ontológica que deveria ocorrer dentro de uma sociedade verdadeiramente comprometida com a democracia, indivíduos brancos podem gozar dela porque não são sujeitos sociais marcados, eles são a referência cultural. É então curioso notar como a questão da exclusão e do privilégio afeta diversas esferas da vida das pessoas. Enquanto pessoas brancas podem planejar a vida afetiva delas sem preocupações de exclusão sistemática no mercado de trabalho, pessoas negras sempre sofrem com a possibilidade de desestruturação familiar em função do racismo em várias dimensões da vida social. Uma pessoa branca pode usar o cabelo africano hoje e adotar outro estilo amanhã. Já uma pessoa negra sempre sofrerá exclusões por causa do referencial estético branco (BLACK; STONE, 2005). 
Obviamente, a questão do privilégio não se resume a problemas de ordem pessoal. O que observamos no debate sobre políticas de inclusão racial é uma recusa de parte do judiciário em questionar o privilégio racial, o que não poderia nos surpreender, uma vez que eles também se recusam a reconhecer a exclusão racial. O maior problema do privilégio é a sua invisibilidade social. Os que se beneficiam dos sistemas de exclusão acreditam que suas oportunidades decorrem exclusivamente de seus méritos pessoais, o que não poderia ser mais distante em uma sociedade baseada na desigualdade. Vemos então que a mesma dificuldade de comunicação que impediu a continuidade daquele namoro também dificulta imensamente um consenso entre juristas negros já que eles falam de realidades construídas a partir de pressupostos inteiramente distintos.

\section{QUAL É O SENTIDO DA IGUALDADE PARA UM JURISTA NEGRO?}

Um jurista que pensa como um negro deve rejeitar o individualismo e o universalismo como princípios centrais de interpretação da igualdade. Essa perspectiva precisa ser afastada porque ela parte do pressuposto de que a igualdade exige apenas tratamento simétrico. Como afirmei reiteradamente neste artigo, ao pressupor que todas as pessoas possuem a mesma vivência, essa perspectiva permite a desconsideração do contexto histórico e social no processo de interpretação da igualdade. Análises que possuem um caráter meramente procedimental impossibilita a emancipação de minorias raciais porque elas estão preocupadas apenas com relações de racionalidade entre meios e fins. Essa compreensão descontextualizada impede que a situação de subordinação permanente da população negra seja reconhecida, o que torna esse princípio uma forma de opressão da população negra. A defesa de uma concepção meramente negativa desse princípio é uma forma de dominação racial porque causa um impacto negativo tremendo nesse segmento. Dizer que a igualdade é um princípio que procura apenas identificar formas de irracionalidade significa anular seu potencial emancipatório ${ }^{24}$.

Um jurista que pensa como um negro não pode perder de vista o fato de que a igualdade é um elemento central da noção de cidadania, princípio que sempre procurou garantir a integração social na história das sociedades democráticas. Por esse motivo, devemos interpretar a igualdade a partir do seu potencial de promover a transformação do status social de grupos subordinados $^{25}$. Promover a isonomia significa fomentar a igualdade de status entre grupos e não

\footnotetext{
${ }^{24}$ Ver, por exemplo, BRASIL. Supremo Tribunal Federal, Ação Direta de Inconstitucionalidade No. 3330, Órgão Julgador: Tribunal Pleno, Relator: Carlos Ayres Brito, 03.05.2016 ("Ora bem, que é o desfavorecido senão o desigual por baixo? E quando esse tipo de desigualdade se generaliza e perdura o suficiente para se fazer de traço cultural de um povo, é dizer, quando a desigualdade se torna uma característica das relações sociais de base, uma verdadeira práxis, aí os segmentos humanos tidos por inferiores passam a experimentar um perturbador sentimento de baixa autoestima. Com seus deletérios efeitos na concretização dos valores humanistas que a Magna Lei brasileira bem sintetizou no objetivo fundamental de "construir uma sociedade justa, livre e solidária" (inciso I do art. $3^{\circ}$ ). Pois como negar o fato de que o desigual por baixo, assim macrodimensionado e renitente, se configure como um fator de grave desequilíbrio social? A condenar inteiros setores populacionais a uma tão injusta quanto humilhante exclusão dos benefícios da própria vida humana em comum?"); BRASIL. Tribunal de Justiça de Santa Catarina, Arguição de Inconstitucionalidade No. 2005.021645-7/0001.00, Órgão Julgador: Tribunal Pleno, Relator: Luiz César Medeiros, 27/09/2007 (declarando a inconstitucionalidade de um programa de ações afirmativas em curso superior porque o princípio da igualdade não admite a utilização de critério que viole o ideal da universalidade das normas jurídicas).

${ }_{25}$ Ver nesse sentido BRASIL. Superior Tribunal de Justiça, Recurso Especial 1.132.476, Órgão Julgador: 2a . Turma, Relator: Humberto Martins, 13.10 .2009 (“Ações afirmativas são medidas especiais tomadas com o objetivo de assegurar progresso adequado de certos grupos raciais, sociais ou étnicos ou indivíduos que necessitem de proteção, e que possam ser necessárias e úteis para proporcionar a tais grupos ou indivíduos igual gozo ou exercício de direitos humanos e liberdades fundamentais"); BRASIL, Tribunal de Justiça do Paraná, Ação Cível No. 353602-7, Órgão Julgador: $6^{\mathrm{a}}$. Câmara Cível, Relator: Waldemir Luiz da Rocha, 10.10.2006 (afirmando que a Constituição Federal oferece ampla base legal para a criação de iniciativas governamentais destinadas a promover a integração de grupos tradicionalmente discriminados); BRASIL. Tribunal Regional Federal da 4a. Região, Apelação em Mandado de Revista de Direito Brasileira | São Paulo, SP | v. 18 | n. 7 | p. 393 - 421 | Set./Dez. 2017
} 
apenas entre indivíduos. Meu destino como um homem negro está diretamente relacionado com o destino social das pessoas negras. O nível de apreço social que tenho decorre do tipo de status cultural dos membros da raça negra, fator determinante nas formas de distribuição de oportunidades materiais entre os grupos (FISS, 1977).

É comum a assertiva de que a igualdade é uma referência para a criação de padrões distributivos capazes de garantir as bases necessárias para a ação autônoma dos participantes de uma comunidade política. Esse princípio faz sentido na medida em que fornece referências claras para o tratamento de pessoas que se encontram em situações sociais distintas. Argumenta-se, entretanto, que as concepções de justiça distributiva não dão importância suficiente para as consequências das diferenças de valoração cultural entre os grupos dentro de uma dada sociedade, valorações que fundamentam relações assimétricas de poder. Portanto, essas teorias são problemáticas porque desconsideram os efeitos do tratamento arbitrário das instituições na vida das pessoas. Por esse motivo, a igualdade deve ser vista fundamentalmente como uma forma de relação social e não apenas como um critério distributivo. As interações sociais formam os princípios que determinam padrões de distribuição de oportunidades, um dos motivos pelos quais devemos dar preponderância a elas nas discussões sobre igualdade.

\section{CONCLUSÃO: PENSAR COMO UM NEGRO}

Pensar como um negro significa compreender o Direito como um instrumento de transformação social, como algo que pode ter o poder de afirmar a dignidade do povo negro. Isso exige a rejeição de uma perspectiva interpretativa segundo a qual o sistema jurídico existe para manter o consenso sobre formas de organização social. Uma posição dessa natureza não pode ser apoiada por um jurista que pensa como um negro porque essas normas são produto das relações de poder existente dentro de uma sociedade. Os que estão compromissados com o aspecto transformativo do Direito devem ter em mente que o princípio de isonomia constitucional pretende promover a igualdade de status entre grupos sociais. Isso tem suma importância porque a ideologia do individualismo sempre cria um grave problema para o alcance desse objetivo: ela pressupõe que as pessoas possuem uma vivência separada dos destinos dos grupos aos quais elas pertencem. Nada pode estar mais distante da realidade. A proteção do indivíduo não pode ser a única forma de interpretação da igualdade porque eles existem fundamentalmente como membros de grupos. Um operador do direito que pensa como um negro - e ele pode ser negro ou branco deve estar atento ao fato que as pessoas são excluídas a partir de diferentes vetores de exclusão. Ele também não pode ignorar o fato de que a raça é uma categoria constituída a partir de outras. Isso significa que ela é um meio de exclusão econômica capaz de criar uma classe de subalternos que possuem uma cor específica. Assim, como afirmei antes, pensar como um negro significa possuir uma consciência múltipla, uma consciência capaz de construir empatia com todos aqueles que vivem em uma situação de subordinação.

Pensar como um negro significa reconhecer as relações entre o privilégio branco e a opressão negra. Um jurista que pensa como um negro precisa interpretar a igualdade tendo em vista as relações de poder que estruturam os lugares sociais dos diferentes grupos raciais. Isso significa que ele deve rejeitar a afirmação de que a raça não possui relevância nos processos de

Segurança, No. 2005.70.00.008336-7/PR, Órgão Julgador: 3 ${ }^{\text {a }}$ Turma, Relator: Maria Lúcia Luz Vieira, DE 24/04/2008 (asseverando que a norma constitucional estabelecendo a erradicação da pobreza e da marginalidade como um dos objetivos fundamentais do nosso sistema constitucional implica a implementação de políticas positivas destinadas a eliminar a subordinação social da população negra); BRASIL. Superior Tribunal de Justiça, Mandado de Segurança No. 26.089, Órgão Julgador: 5ª Turma, Relator: Felix Fischer, DJ 12/05/2008 (afirmando que a emancipação de grupos sociais é um dos objetivos principais da noção de igualdade material uma vez que esse princípio procura estabelecer a igualdade de resultados) 
estratificação. Argumentos dessa natureza encobrem o fato que a raça designa uma relação de poder e estabelece o lugar que negros e brancos ocupam dentro da sociedade. É por meio dela que lugares sociais são prescritos, é por meio dela que sujeitos sociais são construídos. Infelizmente, esse processo permanece encoberto por uma epistemologia da ignorância, elemento central da ideologia racial brasileira. A compreensão da raça como uma categoria meramente formal no processo de interpretação promove a invisibilidade do racismo. É por esse motivo que o jurista que pensa como um negro deve estar comprometido com uma interpretação da Constituição Federal que possa promover a igualdade de status entre grupos. Ele não pode perder de vista o fato de que as pessoas são discriminadas porque pertencem a certas comunidades, pertencimento que indica uma forma de identidade que determina a vida das pessoas. Assim, a igualdade deve ser voltada para a proteção de grupos sociais, única forma de promovermos uma transformação da nossa nação.

\section{REFERÊNCIAS BIBLIOGRÁFICAS}

APPIAH, K. Anthony. Stereotypes and the shapping of identity. California Law Review. v. 88, n. 1, p. 41-53, 1985.

BELL. Derick. And we are not saved. The elusive quest for racial justice. Boston: Basic Books, 1989.

BLAKE, Linda L.; STONE, David. Expanding the definition of privilege: the concept of social privilege. Journal of Multicultural Counseling and Development. v. 33, p. 243-255, 2005.

BLUMER, Herbert. Prejudice as a sense of group position. Pacific Sociological Review. v. 1, n. 1, p. 3-7, 1958.

CRENSHAW, Kimberlé. Demarginalizing the intersection of race and sex: A black feminist critique of antidiscrimination doctrine, feminist theory and antiracist policits. University of Chicago Legal Forum, v. 1989, n. 1, pp. 139 - 167, 1989.

CULP JR. Jerome McCristal. Toward a black legal scholarship: race and original understandings. Duke Law Journal, v. 1991, n. 1, p. 39-105, 1991.

DELGADO, Richard \& STEFANCIC, Jean. Critical race theory. An introduction. New York: New York University Press, 2001.

DOMINGUES, Petrônio. Uma história não contada. Negro, racismo e branqueamento em São Paulo no pós-abolição. São Paulo: SENAC, 2004.

EMYRBAYER, Mustafa; DESMOND, Matthew. The racial order. Chicago: University of Chicago Press, 2015.

ESTLUND, Cynthia L. Putting Grutter to work: diversity, integration, and affirmative action in the workplace. Berkeley Journal of Employment and Labor Law, v. 26, n. 1, p. 2 - 40, 2005.

FAUSTO, Boris. História do Brasil. 14 ed. São Paulo: Edusp. 2013. 
FISS, Owen. Groups and the equal protection clause. Philosophy and Public Affairs, v. 5, n. 2, p. $107-167,1976$.

FITZPATRICK, Peter. Racism and the innocence of law. Journal of Law and Society. v. 14, n. 1, 119-132, 1987.

FLAGG, Barbara. "Was blind, but now I see": white race consciousness and requirement of discriminatory intent. Michigan Law Review. v. 91, n. 3, p. 953-1017, 1993.

FRASER, Nancy. Redistribuição, reconhecimento e participação: por uma concepção integrada de justiça. In: SARMENTO, D.; IKAWA, D.; PIOVESAN, F. (eds.). Igualdade, diferença e direitos humanos. Rio de Janeiro: Lumem Juris, 2008.

FREEMAN, Alan. Legitimizing discrimination through antidiscrimination law. A critical review of Supreme Court doctrine. Minnesota Law Review, v. 62, n.4, p. 1048 - 1118, 1978.

FRY, Peter et al. Race and genomic ancestry in Brazil: dialogues between anthropology and genetics. Current Anthropology, v. 50, n. 6, p. 787 - 819, 2009.

GADAMER, Hans-George. Verdade e método. Traços fundamentais de uma hermenêutica filosófica. Petropólis: Vozes, 1999.

GREEN, Tristin. A structural approach as antidiscrimination mandate: locating employer wrong. Vanderbilt Law Review. v. 60, n. 3, p. 849-904, 2007.

HANCHARD, Michel. Orpheus and power: the movimento negro of Rio de Janeiro and Salvador, 1945 - 1988. Princeton: Princeton University Press, 1994.

HASENBALG, Carlos. Discriminação e desigualdades raciais no Brasil. Belo Horizonte: Editora da UFMG, 2005.

HUNT III, Cecil J. The color of perspective: affirmative action and the constitutional rhetoric of affirmative action. Michigan Journal of Race and Law, v. 11, n. 3, p. 477 - 545, 2005.

IENSUE, Geziela; CARVALHO, Luciani Coimbra de. Educação e ações afirmativas como direito á participação e ao procedimento. Revista de Direito Brasileira, v. 10, n. 5, p. 200 - 227, 2015.

JACCOUD, Luciana (org.). A construção de uma política de igualdade racial: uma análise dos últimos 20 anos. Brasília: IPEA, 2009.

KANG, Jerry. Trojan horses of race. Harvard Law Review. v. 118, n. 4, p. 1401-1593, 2004.

KAUFMANN, Roberta Fragoso. Ações afirmativas à brasileira: necessidade ou mito. Curitiba: Livraria do Advogado, 2005. 
KENNEDY, Duncan. A critique of adjudication. Fin de siècle. Cambridge: Harvard University Press, 1989.

KLARE, Karl. Legal culture and transformative constitutionalism. South African Journal of Human Rights, v. 146, n. 1, 146 - 188, 1998.

LANGA, Pius. Transformative Constitutionalism. Stellenbosch Law Review, v. 17, n. 3, p. 351 360, 2006.

LIPPERT-RASMUSSEN, Kasper. Born free and equal?: a philosophical inquiry into the nature of discrimination. Oxford: Oxford University Press, 2014.

LIPSITZ, George. The possessive investment in whiteness. How white people profit from identity politics. Philadelphia: Temple University Press, 2006. 291 p.

LOOMBA, Ania. Colonialism/postcolonialism. New York: Routledge, 2005.

MAGGIE, Yvonne. Políticas de cotas e o vestibular da UNB ou a marca que cria sociedades divididas. Horizontes Antropológicos, v. 11, n. 23, p. 286 - 291, 2005.

MATSUDA, Mari. Looking from the bottom: critical legal studies and reparations. Harvard Civil Rights - Civil Liberties Law Review, v. 22, n. 2, p. 322 - 396, 1987.

MATTOS, Hebe. Das cores do silêncio. 2a ed. Campinas: Editora Unicamp, 2013.

MIGNOLO, Walter D. The geopolitics of knowledge and the colonial difference. The South Atlantic Quarterly, v. 101, v. 1, p. 57 - 95, 2002.

MILLS, Charles. The racial contract. Ithaca: Cornell University Press, 1997.

MINDA, Gary. Postmodern legal movements. New York: New York University Press, 1995.

MOREIRA, Adilson José. O Mito da Inocência Branca no Debate Brasileiro sobre Ações Afirmativas. In: Liliana Lyra Jubilut, José Luis Quadros de Magalhães, Alexandre Gustavo Melo Franco Bahia. (Org.). Direito à Diferença: Aspectos de Proteção Específica às Minorias e Grupos Vulneráveis. 1ed.São Paulo: Saraiva, 2013, v. 2, p. 61 - 94.

MOREIRA, Adilson José. O que é discriminação? São Paulo: Letramento, 2017.

MINDA, Gary. Postmodern legal movements. New York: New York University Press, 1995.

NASCIMENTO, Abdias do; NASCIMENTO, Elisa Larkin. Dance of deception: a Reading of race relations in Brazil. In: HAMILTON, Charles V. et al. (orgs.). Beyond racism. Race and inequality in Brazil, South Africa, and the United States. Londres: Rienner Publishers, 2001, p. $105-156$. 
OMI, Michael \& WINANT, Howard. Racial formation in the United States. From the 1960s to 1990s. New York: Routledge, 1994.

PENA, Sérgio; BORTOLINI, Maria Katia. Pode a genética definir quem deve se beneficiar das cotas universitárias e demais ações afirmativas? Estudos Avançados, v. 18, n. 50, p. 31 - 50, 2004.

SANTOS, Ricardo Ventura: MAIO, Marcos Chor. Qual "retrato do Brasil”? Raça, biologia, identidades e política na era da genômica. Mana, v. 10, n. 1, p. 61 - 95, 2004.

TELLES, Edward. Race in another America: the significance of skin color in Brazil. Princeton: Princeton University Press, 2004. 334 p.

WILLIAMS, Patricia. The alchemy of race and rights. Cambridge: Harvard University Press, 1992. 